Article

\title{
Evaluation of Particleboards Made from Giant Reed (Arundo donax L.) Bonded with Cement and Potato Starch
}

\author{
Aranzazu Alejandra Ferrandez-García, Teresa Garcia Ortuño, Manuel Ferrandez-Villena *(D), \\ Antonio Ferrandez-Garcia and Maria Teresa Ferrandez-García (D)
}

check for

updates

Citation: Ferrandez-García, A.A.;

Ortuño, T.G.; Ferrandez-Villena, M.;

Ferrandez-Garcia, A.; Ferrandez-

García, M.T. Evaluation of

Particleboards Made from Giant

Reed (Arundo donax L.) Bonded with

Cement and Potato Starch. Polymers

2022, 14, 111. https://doi.org/

10.3390/polym14010111

Academic Editors: Domenico

Acierno and Antonella Patti

Received: 28 November 2021

Accepted: 24 December 2021

Published: 29 December 2021

Publisher's Note: MDPI stays neutral with regard to jurisdictional claims in published maps and institutional affiliations.

Copyright: (C) 2021 by the authors. Licensee MDPI, Basel, Switzerland. This article is an open access article distributed under the terms and conditions of the Creative Commons Attribution (CC BY) license (https:// creativecommons.org/licenses/by/ $4.0 /)$
Department of Engineering, Universidad Miguel Hernández, 03300 Orihuela, Spain; aranfer2@gmail.com (A.A.F.-G.); tgarcia@umh.es (T.G.O.); antonio.ferrandezg@umh.es (A.F.-G.); mt.ferrandez@umh.es (M.T.F.-G.)

* Correspondence: m.ferrandez@umh.es; Tel.: +34-966-749-716

\begin{abstract}
There is a general concern about the rationalization of resources and the management of waste. Plant residues can contribute to the development of new non-polluting construction materials. The objective of this study was to valorize a plant residue such as the giant reed and obtain a particleboard with cement using potato starch as a plasticizer in a manufacturing process involving compression and heat. The influence of cement and starch in different proportions and its stability over time were analyzed. Finally, their physical and mechanical properties were evaluated and compared to European Standards. High-quality sustainable particleboards (boards with high structural performance) were obtained and can be classified as P6 according to European Standards. Mechanical properties were improved by increasing the starch content and pressing time, whereas greater resistance to water was obtained by increasing the cement content. Giant reed particles seem to tolerate the alkalinity of the cement since there was no sign of degradation of its fibers. The use of these residues in the manufacture of construction materials offers a very attractive alternative in terms of price, technology and sustainability.
\end{abstract}

Keywords: composite; MOR; MOE; IB; panel

\section{Introduction}

Environmental awareness is increasing in society and with it, public concern about the rationalization of resources and the management of waste. One way to collaborate in solving both problems is by increasing the use of construction materials composed of plant fibers, given these products are easily recyclable and are not aggressive with the environment. The recovery of this waste is also in agreement with European policies related to the environment [1-3]. The manufacturing of products from plant residues avoids their elimination through incineration, reducing greenhouse gas emissions by fixing carbon during their life cycle. This could help EU member states fulfill their agreements ensuring that accounted greenhouse gas emissions from land use, land use change or forestry (LULUCF) are balanced by at least an equivalent accounted removal of $\mathrm{CO}_{2}$ from the atmosphere in the period 2021 to 2030 [4].

Cement-bonded wood composite panels are not a novel concept, having been on the market during the past century [5]. Cement traditionally has been used to strengthen wood composites improving their mechanical performance [6,7], fire retardance, water resistance and insulation [8]. These products are currently used by the construction industry in applications such as walls, roof sheathing and tiles, floor, fences and sound barriers [9-11]. However, due to a decreasing availability of wood, there has been a deterioration in the mechanical properties of these commercial composites.

Studies are currently oriented towards the production of new generation composite boards with lignocellulosic residues of agricultural origin. The development of biorenewable materials mixed with cement provides added value for the agricultural waste 
market. The main advantages of using lignocellulosic materials as reinforcement in cement are their low density, low cost, biodegradability, availability of large varieties of fibers throughout the world and the promotion of a new agricultural economy [12,13].

A variety of investigations of plant fibers with cements have been studied: rattan [14], bamboo [15], rice husk [16], sisal [17-19], coconut [20-26], sugar cane bagasse [27-29], babaçu [30], banana [31,32], coconut and abaca [33], oil palm [34-36], canary palm [37], arhar [38], agave lecheguilla [39], date palm [40], hemp [41-45], kenaf [46], giant reed [47], hazelnut shell, wood and tea [48], cork [49], jute [50,51] and corn [52].

Composites made of natural fibers absorb a large amount of water causing cracking due to the swelling of the fibers. The initial curing process of cement compounds with plant biomass is problematic due to the loss of water absorbed by the fibers. However, later internal curing is favored by the release of part of the water that the biomass had captured. Natural fibers with cement composites are more susceptible to a lack, rather than an excess, of water. High amounts of water in the cement-fiber mix cause the segregation of the mixture, whereas small amounts of water make compaction of the mixture difficult and favors the presence of heterogeneities.

Another issue is that plant fibers suffer degradation when in contact with cement. Some investigations have focused on the modification of the surface of the fibers in order to prevent degradation $[40,46,53-56]$. The properties of these composites are limited by a combination of factors such as heterogeneity, wettability and chemical compatibility of the natural fibers with cement. Composites reinforced with lignocellulosic material present a great variability in their mechanical properties in cement boards due to the deterioration of their properties because of alkaline degradation (hydrolysis) and fiber mineralization [57]. These mechanisms produce changes in the chemical composition of the fibers that cause a reduction in strength and degradation of the polymeric matrix, of the fiber/polymer matrix interfacial bond [57] and also of plant fibers resulting in a delay in the cement hydration [31].

Various components of the biomass, such as soluble sugars or low molar mass hemicelluloses, have adverse effects on the preparation and performance of concrete [58]. Therefore, selecting biomass sources with a low content of these compounds would minimize these drawbacks. Research on starch-based lightweight concrete has investigated the effect of its polysaccharides on cement $[59,60]$, the retardant properties of the starch for cement setting [61], the dispersion mechanism of sulfonated starch as a water-reducing agent for cement [62], jute-cement panels with different proportions of starch [63] and particles of palm tree with cement and starch [37].

Different manufacture parameters of panels made of cement with lignocellulosic materials have been analyzed, concluding that cemented panels are high-strength construction materials. However, their industrial production requires a high investment and further research is needed to reduce cost manufacturing [64] and to evaluate the effects of fiber pretreatment methods and alternative curing methods for the long-term performance of these composites $[12,65]$.

Giant reed (Arundo donax L.) is one of the largest species of grass growing in Mediterranean regions. It is a wild perennial plant to which no genetic improvement or genotype selection has been made. It grows annually, with average heights of $4 \mathrm{~m}$ and a mean thickness of $4 \mathrm{~cm}$. Reed has traditionally been used in many Mediterranean countries. In the southeast of Spain, it was used in construction as part of the roof and floor up to the beginning of the 20th century. However, it is now in disuse and has become an environmental problem since it forms dense reed beds along river banks. When the water level rises, the reeds are uprooted and carried away on the current, forming large masses that block watercourses, causing flooding and sweeping away any structure that gets in their way. In the Segura River in Spain, the authorities are forced to make significant economic investments in order to keep reeds controlled, hence they are cleaned and processed in authorized landfills [66]. 
Several authors used giant reed biomass to obtain particle-boards with different adhesives. A study on multilayer panels of oriented particles [67] found that these boards have good mechanical behavior and were therefore suitable for use in load-bearing structures according to European Standards [68]. With urea formaldehyde (UF), Garcia Ortuño et al. [69] obtained panels with good properties of modulus of rupture $\left(17.67 \mathrm{~N} / \mathrm{mm}^{2}\right)$, modulus of elasticity $\left(3025.90 \mathrm{~N} / \mathrm{mm}^{2}\right)$ and internal bounding strength $\left(1.31 \mathrm{~N} / \mathrm{mm}^{2}\right)$ that could be commercialized. Giant reed particleboards have also been manufactured with unmodified starches [70] and presented good mechanical properties (modulus of rupture of $16.20 \mathrm{~N} / \mathrm{mm}^{2}$, modulus of elasticity of $2520.97 \mathrm{~N} / \mathrm{mm}^{2}$ and internal bounding strength of $0.39 \mathrm{~N} / \mathrm{mm}^{2}$ ) through a cyclical process of humidification, heat and pressure. The best properties were found when potato starch was used as an adhesive. In other tests of giant reed with cement mortars, Shon [71] observed that the thermal conductivity and density of the concrete decreased.

Plant residues can contribute to the developing of new non-polluting construction materials. The objective of this research was to valorize a plant residue such as the giant reed and obtain a particleboard, adding a very small amount of cement in comparison with the wood-cement composites and using potato starch as a plasticizer in a manufacturing process involving compression and heat. The influence of cement and starch in different proportions and its stability over time were analyzed. Finally, the particleboard's physical and mechanical properties were evaluated and compared to European Standards [68] in order to verify whether it could be used as a building material.

\section{Materials and Methods}

\subsection{Materials}

The materials used were residues of giant reed (Arundo donax L.) and different proportions of CEM II/B-LL 32.5 N Portland cement, potato starch (Solanum tuberosum) and water.

The giant reed biomass (Figure 1) was obtained from clearing the banks of the Segura River in southeast Spain. The reeds were laid out in a vertical position to dry outdoors for 12 months until their relative humidity was $8.2 \pm 0.4 \%$. They were then cut and shredded in a blade mill. The particles were collected in a vibrating sieve and only those that passed through the $0.25 \mathrm{~mm}$ sieve were selected.

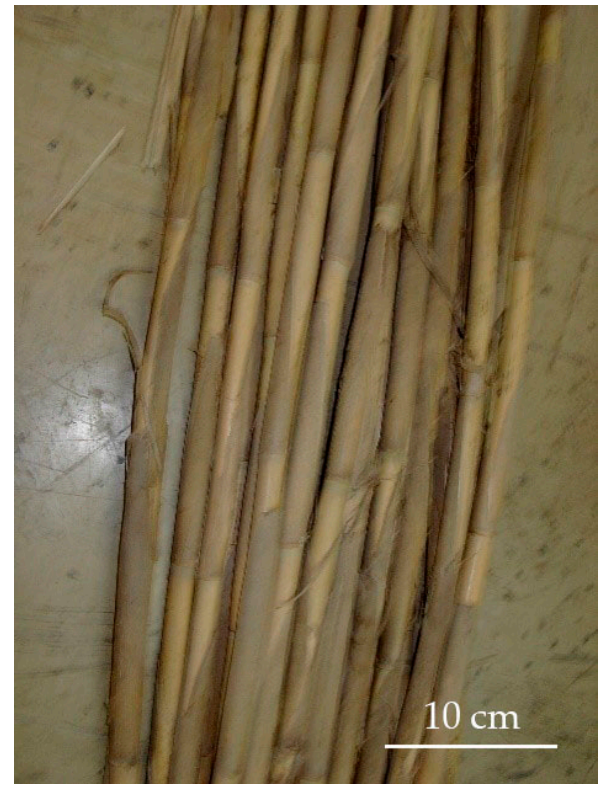

Figure 1. Giant reed used in the manufacturing of the panels.

Potato starch from the food industry, with $90 \%$ purity, was used as a plasticizer. Chemically, starch is a mixture of two similar polysaccharides: amylose and amylopectin. 
Potato starch typically contains large oval granules and gels at a temperature of $58-65{ }^{\circ} \mathrm{C}$. Water was taken directly from the mains water supply, with an average temperature of $20{ }^{\circ} \mathrm{C}$.

\subsection{Manufacturing Process}

The manufacturing process consisted of combining dry reed particles with cement in different proportions in weight (0,10 and 20\%) and starch (0,5 and 10\%). Then, 10\% water was sprayed onto the mixture before stirring it for $15 \mathrm{~min}$ in a blender (LGB100, Imal s.r.l., Modena, Italy) until homogenized.

The mat, formed in a mold of dimensions $600 \mathrm{~mm} \times 400 \mathrm{~mm}$, was then placed in a hot press with a force of $2.6 \mathrm{MPa}$, a temperature of $100{ }^{\circ} \mathrm{C}$ and four different times $(1,2,3$ and $4 \mathrm{~h}$ ). Subsequently, the boards were cooled to room temperature. A total of 132 panels were made, comprising seven types with four different classes (the 28 different configurations are shown in Tables 1 and 2).

Table 1. Types of panels manufactured.

\begin{tabular}{cccc}
\hline \multirow{2}{*}{ Type } & Number of Panels & \multicolumn{2}{c}{ Weight Dosage (\%) } \\
\cline { 3 - 4 } & & Starch & Cement \\
\hline A & 20 & 10 & 20 \\
\hline B & 20 & 5 & 20 \\
\hline C & 20 & 10 & 10 \\
\hline D & 20 & - & 10 \\
\hline E & 20 & - & 20 \\
\hline F & 16 & 5 & - \\
\hline G & 16 & 10 & - \\
\hline
\end{tabular}

Table 2. Division of panels in classes according to their pressing time.

\begin{tabular}{ccc}
\hline Pressing Time (h) & Class & Number of Panels \\
\hline 1 & 1 & 4 \\
\hline 2 & 2 & $8^{1}$ \\
\hline 3 & 3 & 4 \\
\hline 4 & 4 & 4
\end{tabular}

${ }^{1}$ Only for types $\mathrm{A}$ to E. For types $\mathrm{F}$ and $\mathrm{G}$, the number of panels was four.

Twenty-eight days after manufacture, four specimens of each type (A to $G$ ) and class (1 to 4 ) were cut to the appropriate dimensions as indicated in European Standards [72] in order to carry out the tests needed to characterize the mechanical, physical and thermal properties of each of the boards being studied (Figure 2). Three hundred and sixty-five days after manufacture, four boards of class 2 from types A to E were cut and also tested. 


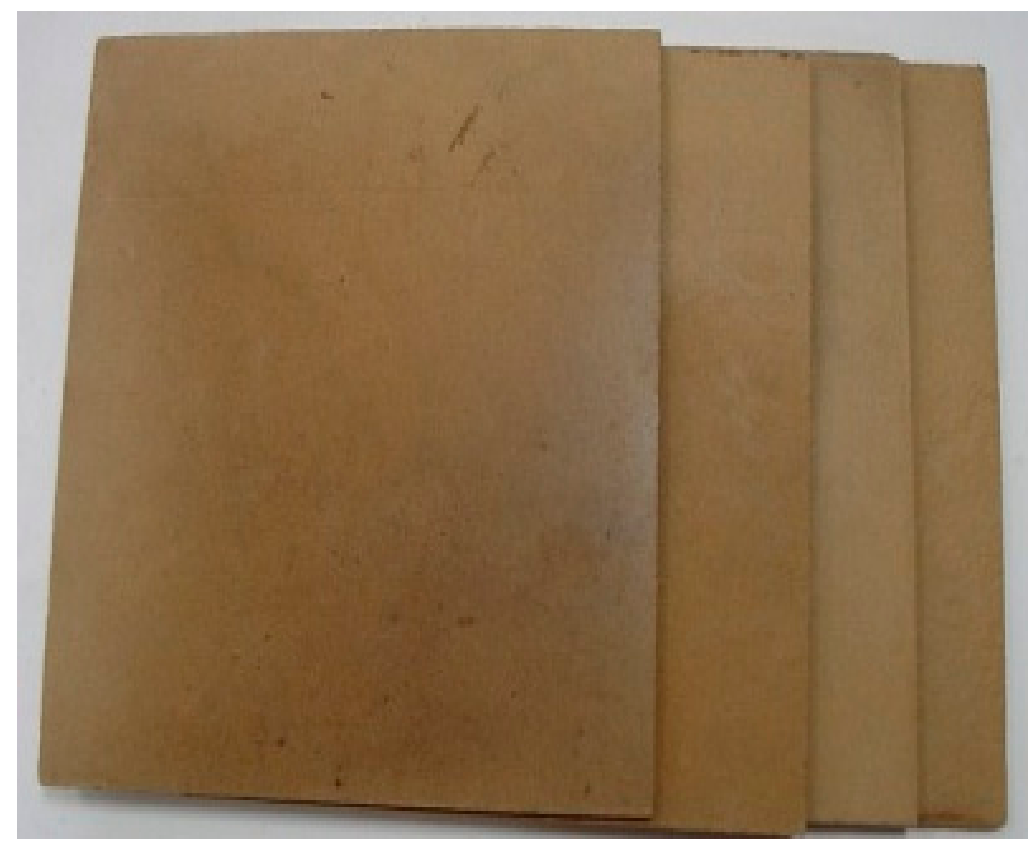

Figure 2. Giant reed-cement-starch panels.

\subsection{Methods}

The method followed was experimental. The tests were conducted in the Materials Strength Laboratory of the Higher Technical College of Orihuela at Universidad Miguel Hernández, Elche. The values were determined according to European Standards established for wood particleboards [73].

After they were manufactured and cut, density [74], thickness swelling (TS) and water absorption (WA) after 2 and $24 \mathrm{~h}$ immersed in water [75], internal bonding strength (IB) [76], modulus of elasticity (MOE) and modulus of rupture (MOR) [77] were measured (Table 3). Later, the boards were evaluated according to European Standards [68]. In order to assess the resistance of the reed particles to the alkalinity of the cement, MOR and MOE tests were performed after 365 days on four class 2 panels of types A to E.

Table 3. Characteristics of the tests performed.

\begin{tabular}{ccccc}
\hline Test & $\begin{array}{c}\text { N of Replicates } \\
\text { (Per Panel) }\end{array}$ & $\begin{array}{c}\text { N of Replicates } \\
\text { (Total) }\end{array}$ & $\begin{array}{c}\text { Size of the } \\
\text { Specimens }\end{array}$ & Equipment Used \\
\hline Relative Humidity & 3 & 396 & $20 \mathrm{~g}$ & Model UM2000, Imal s.r.l. \\
\hline Density & 6 & 792 & $50 \mathrm{~mm} \times 50 \mathrm{~mm}$ & Model IB700, Imal s.r.l. \\
\hline Thickness Swelling (TS) & 3 & 396 & $50 \mathrm{~mm} \times 50 \mathrm{~mm}$ & $\begin{array}{c}\text { Model 76-B0066/B Water } \\
\text { Bath, Controls S.A. } \\
\text { Model UM2000, Imal s.r.l. }\end{array}$ \\
\hline Water Absorption (WA) & 3 & 396 & $50 \mathrm{~mm} \times 50 \mathrm{~mm}$ & $\begin{array}{c}\text { Model 76-B0066/B Water } \\
\text { Bath, Controls S.A. } \\
\text { Model UM2000, Imal s.r.l. }\end{array}$ \\
\hline Modulus of Rupture (MOR) & 6 & 792 & $150 \mathrm{~mm} \times 50 \mathrm{~mm}$ & Model UM2000, Imal s.r.l. \\
\hline Modulus of Elasticity (MOE) & 6 & 792 & $150 \mathrm{~mm} \times 50 \mathrm{~mm}$ & Model UM2000, Imal s.r.l. \\
\hline Internal Bonding Strength (IB) & 3 & 396 & $50 \mathrm{~mm} \times 50 \mathrm{~mm}$ & Model UM2000, Imal s.r.l. \\
\hline
\end{tabular}

The morphology of the inside of the experimental panels was examined using a scanning electron microscope (SEM) (Hitachi model S3000N, Hitachi, Ltd., Tokyo, Japan) equipped with an X-ray detector (Bruker XFlash 3001, Billerica, MA, USA). For the observations, images of fractured $5 \mathrm{~mm} \times 5 \mathrm{~mm}$ cross-sections of the panels were taken. 
The moisture content of the material was measured with a laboratory moisture meter (model UM2000, Imal s.r.l., Modena, Italy). The water immersion test for the panels was carried out in a heated tank (Model 76-B0066/B Water Bath, Equipos de Ensayo Controls S.A., Toledo, Spain).

The mechanical tests and density were performed with the universal testing machine (model IB700, Imal s.r.1., Modena, Italy), which complies with the velocity of $5 \mathrm{~mm} \cdot \mathrm{min}^{-1}$ for the bending test and $2 \mathrm{~mm} \cdot \mathrm{min}^{-1}$ for internal bonding strength.

For the statistical analysis, SPSS v. 26.0 software (IBM, Chicago, IL, USA) was used. Analysis of variance (ANOVA) was performed for a significance level of $\alpha<0.05$. The standard deviation was obtained for the mean values of the tests.

\section{Results}

\subsection{Physical Properties}

Average density is showed in Figure 3, with all boards considered to have mediumhigh density. Boards made with starch alone $(F, G)$ had a density range from 866 to $988 \mathrm{~kg} / \mathrm{m}^{3}$, those with cement alone (D, E) were from 942 to $1026 \mathrm{~kg} / \mathrm{m}^{3}$ and those with starch and cement (A, B, C) were from 990 to $1116 \mathrm{~kg} / \mathrm{m}^{3}$. Boards manufactured with a mix of cement and starch have higher density than using these two components separately. The boards with the highest density were B4 class, with a composition of 5\% potato starch and $20 \%$ cement. They were in the hot plate press for $4 \mathrm{~h}$, reaching an average density of $1116 \mathrm{~kg} / \mathrm{m}^{3}$.

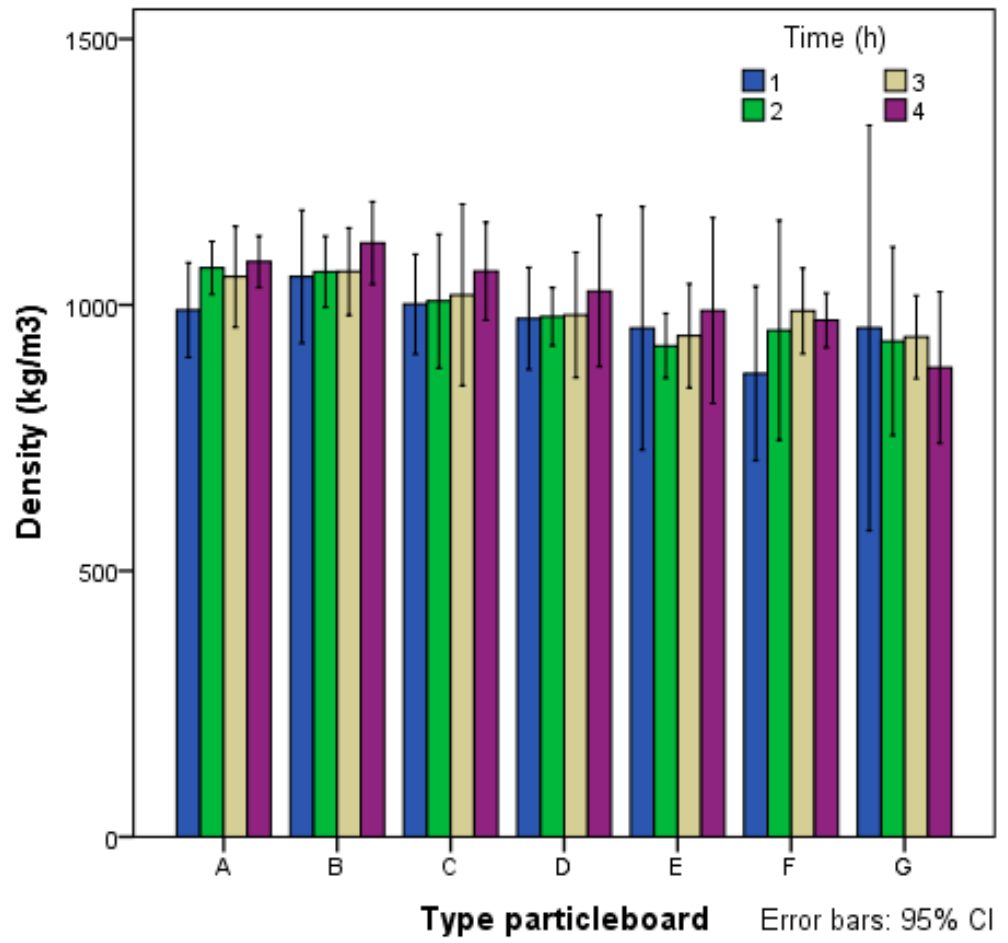

Figure 3. Mean density of type A-G particleboards.

Figure 4 shows the mean values of the thickness swelling tests (TS) and water absorption (WA) after $24 \mathrm{~h}$ of immersion in water. The boards with starch alone (F, G) had a TS from 37.2 to $56.3 \%$, with cement $(\mathrm{D}, \mathrm{E})$ ranging from 26.7 to $58.5 \%$ and starch and cement $(\mathrm{A}, \mathrm{B}, \mathrm{C})$ from 11.5 to $23.8 \%$. WA follows the same tendency of TS. Type B, made with $5 \%$ starch and 20\% cement, had the lowest WA value between 37.27 and $43.85 \%$. Panels made of cement and starch achieved a great result and could be classified as structural boards. 


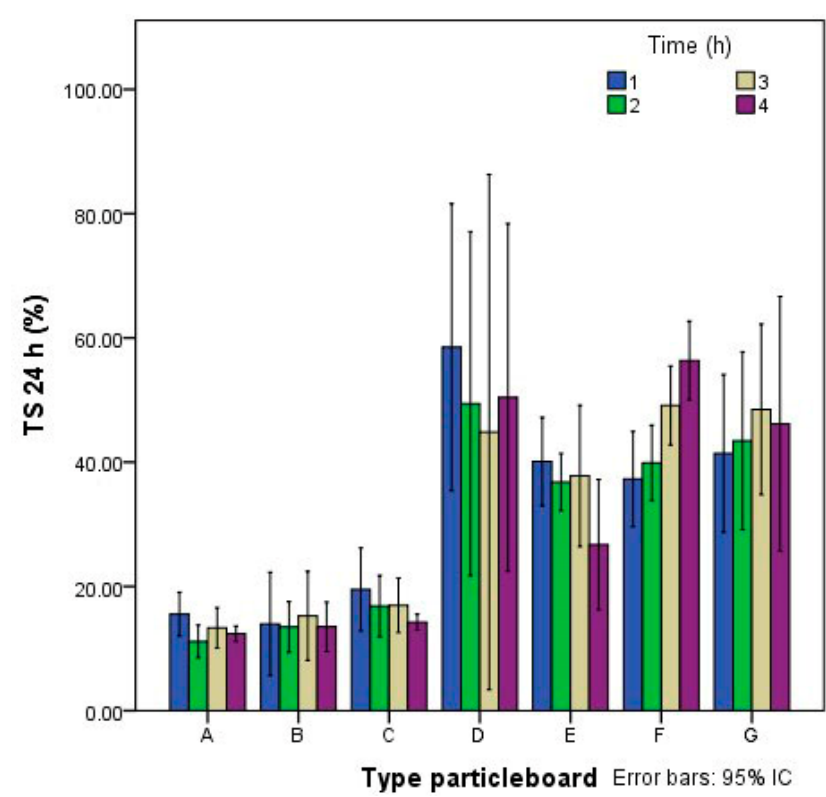

(a)

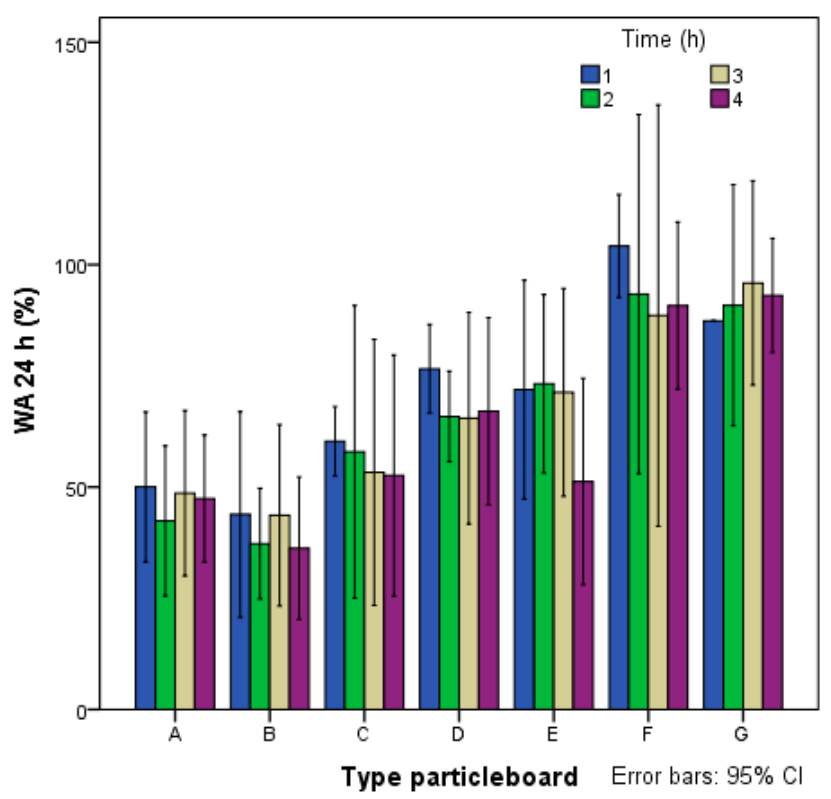

(b)

Figure 4. (a) Thickness swelling (TS) after $24 \mathrm{~h}$ and (b) water absorption (WA) after $24 \mathrm{~h}$.

\subsection{Mechanical Properties}

Modulus of rupture (MOR) and modulus of elasticity (MOE) results follow a similar pattern, as shown in Figure 5. MOR performance of the boards made with starch $(\mathrm{F}, \mathrm{G})$ ranged from 7.89 to $18.53 \mathrm{~N} / \mathrm{mm}^{2}$, with cement $(\mathrm{D}, \mathrm{E})$ ranging from 6.21 to $18.04 \mathrm{~N} / \mathrm{mm}^{2}$ and starch and cement $(\mathrm{A}, \mathrm{B}, \mathrm{C})$ from 12.59 to $27.26 \mathrm{~N} / \mathrm{mm}^{2}$. MOE values with starch $(\mathrm{F}, \mathrm{G})$ ranged between 1663.3 and $2763.7 \mathrm{~N} / \mathrm{mm}^{2}$, with cement (D, E) ranging from 1234.8 to $3080.1 \mathrm{~N} / \mathrm{mm}^{2}$ and starch and cement $(\mathrm{A}, \mathrm{B}, \mathrm{C})$ from 1846.1 to $4287.4 \mathrm{~N} / \mathrm{mm}^{2}$.

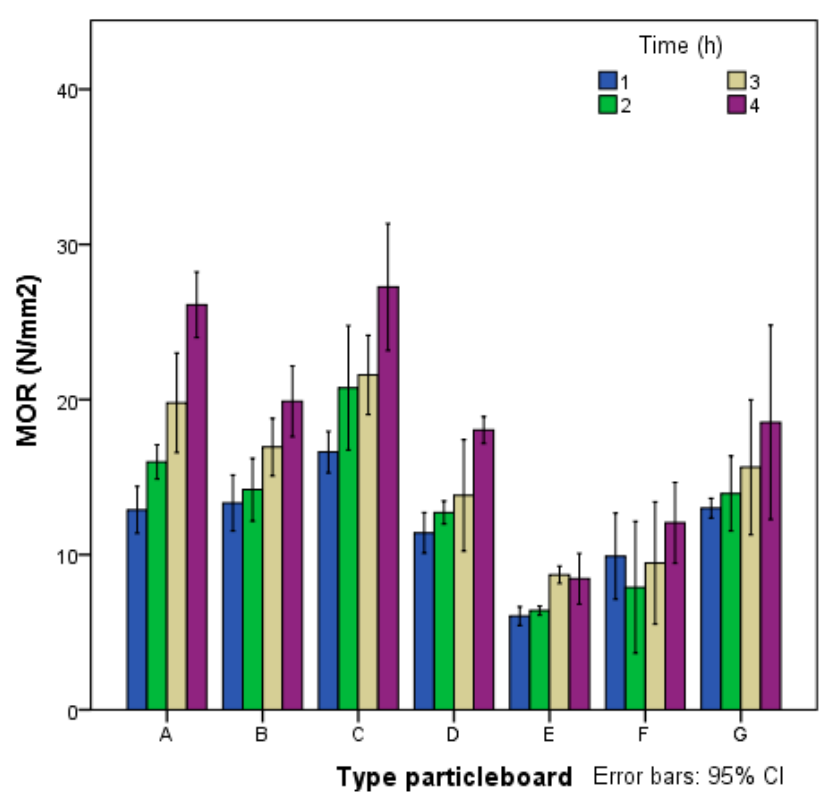

(a)

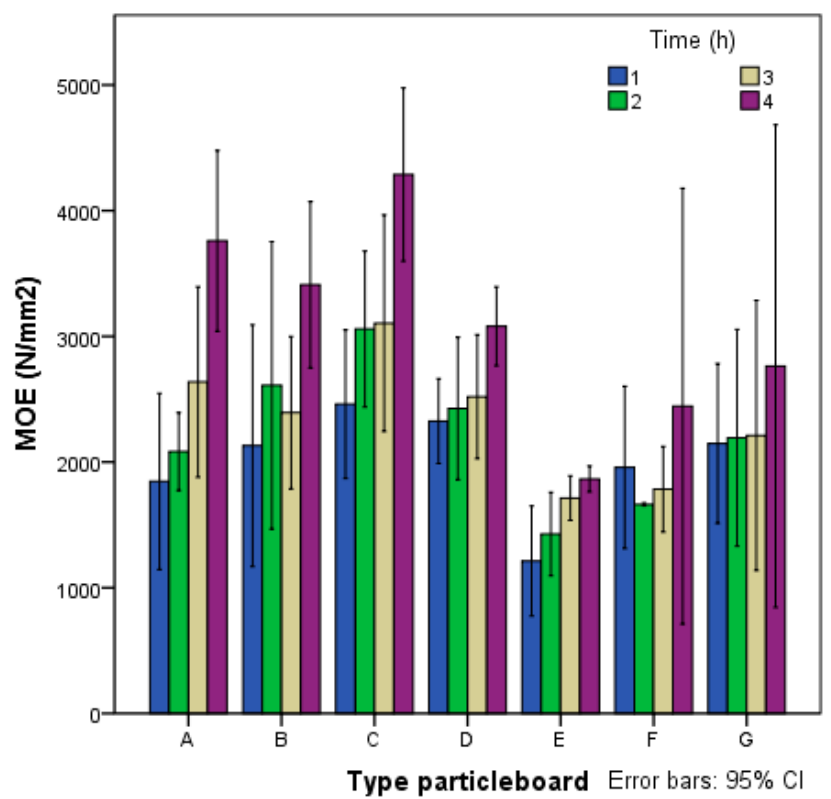

(b)

Figure 5. (a) Modulus of rupture (MOR) and (b) and modulus of elasticity (MOE).

Type $A$ and $C$ boards, using starch and cement and a press time of $1 \mathrm{~h}$, can be classified as P2. After being in the press for $4 \mathrm{~h}$, these panels achieved the P7 requirements. The 
mechanical results obtained were very high, showing the good mechanical properties that can be achieved with boards made of giant reed-cement-starch.

The average values obtained for internal bonding strength (IB) (Figure 6) varied between 0.20 and $0.28 \mathrm{~N} / \mathrm{mm}^{2}$, with starch $(\mathrm{F}, \mathrm{G})$ with cement $(\mathrm{D}, \mathrm{E})$ ranging between 0.15 and $0.36 \mathrm{~N} / \mathrm{mm}^{2}$ and starch and cement $(\mathrm{A}, \mathrm{B}, \mathrm{C})$ between 0.36 and $0.89 \mathrm{~N} / \mathrm{mm}^{2}$.

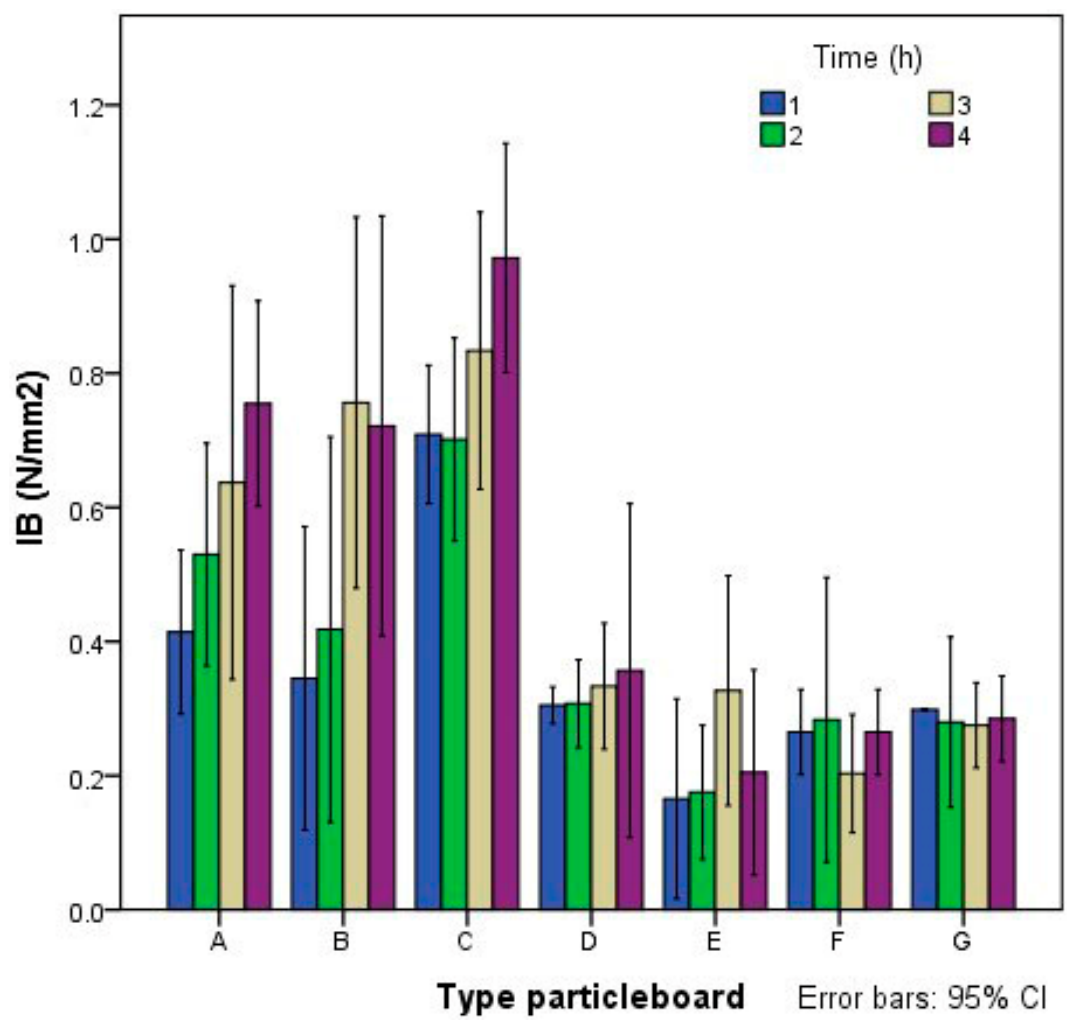

Figure 6. Internal bounding strength.

The results of the test indicate that the contribution of starch improved the properties of the boards, as was observed in the palm-cement boards [37]. Board types A, B and C could be classified as P7, whereas if only cement or starch was used, the boards only met the $\mathrm{P} 1$ requirements.

\subsection{Assessment of the Durability of the Fibers}

To verify that fibers were not degraded in contact with cement, four extra boards of classes A2, B2, C2, D2 and E2 (the types containing cement) were made. These extra specimens were cut for the mechanical tests that were carried out 365 days after manufacture and compared to the others specimens from the same class. The results obtained from MOR and MOE are shown in Figure 7. It can be concluded that boards made with starch and cement (classes A2, B2 and C2) had a significant increase in the MOR and MOE values at 365 days of setting. The boards that only contained cement (classes D2 and E2) presented similar values. 


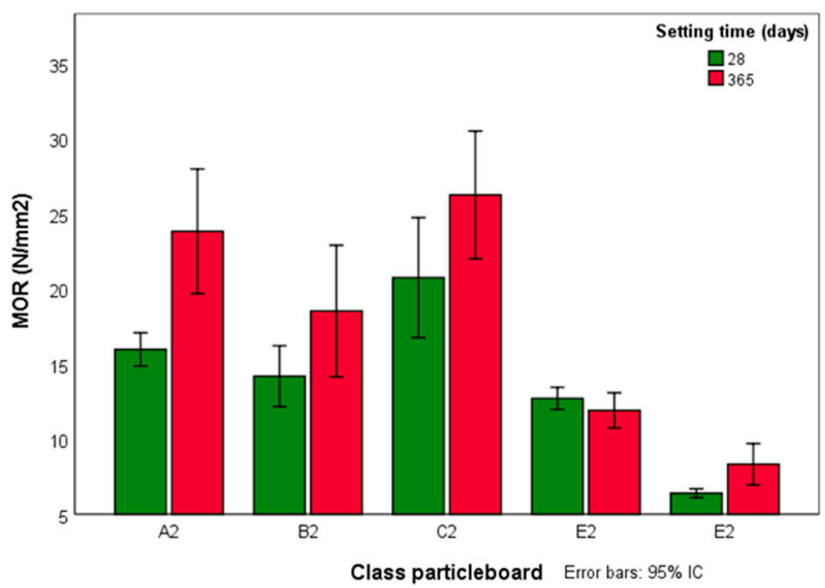

(a)

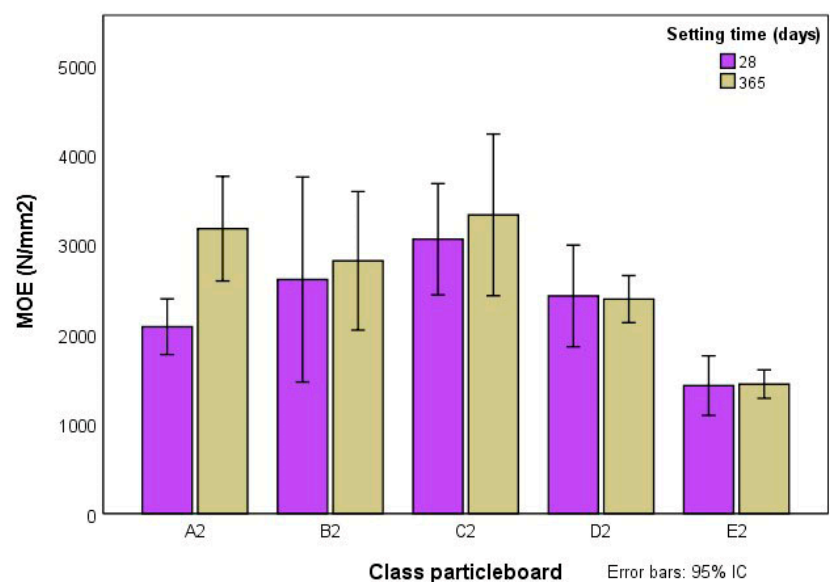

(b)

Figure 7. (a) Modulus of rupture (MOR) and (b) modulus of elasticity (MOE) after 28 and 365 days of cement hydration.

This demonstrates that giant reed particles are not degraded by the alkalinity of the cement, as no deterioration was observed in their mechanical properties. Boards made of reed with cement and starch showed a notable improvement over time that may be justified by the beneficial effect that starch could exert on the setting of the cement. It is possible that the water absorbed by the starch at the beginning of the manufacturing process was gradually transferred to the cement, favoring its subsequent hydration.

\subsection{Statistical Analysis}

The ANOVA shown in Table 4 indicated that density depends on the type of board, whereas the time in the press has no influence. Density also depends on the amount of starch used but not the cement. TS and WA are dependent on the type of board and the amount of cement and starch in the mix. Pressing time is not influential in the physical properties. MOR, MOE and IB are influenced by all factors: type of board, pressing time and amount of cement and starch added to the mix.

Table 4. ANOVA of the test results.

\begin{tabular}{|c|c|c|c|c|c|c|}
\hline Factor & Properties & $\begin{array}{l}\text { Sum of } \\
\text { Squares }\end{array}$ & d.f. & Half Quadratic & F & Sig \\
\hline \multirow{6}{*}{ Type of panel } & $\begin{array}{l}\text { Density } \\
\left(\mathrm{kg} / \mathrm{m}^{3}\right)\end{array}$ & $246,938.733$ & 6 & $41,156.455$ & 8.851 & 0.000 \\
\hline & TS 24 h (\%) & $24,117.087$ & 6 & 4019.514 & 79.859 & 0.000 \\
\hline & WA 24 h (\%) & $30,972.016$ & 6 & 5162.003 & 24.673 & 0.000 \\
\hline & $\operatorname{MOR}\left(\mathrm{N} / \mathrm{mm}^{2}\right)$ & 2203.595 & 6 & 367.266 & 22.757 & 0.000 \\
\hline & $\operatorname{MOE}\left(\mathrm{N} / \mathrm{mm}^{2}\right)$ & $2.572 \times 10^{7}$ & 6 & $4.286 \times 10^{6}$ & 8290 & 0.000 \\
\hline & $\mathrm{IB}\left(\mathrm{N} / \mathrm{mm}^{2}\right)$ & 3.947 & 6 & 0.658 & 10.880 & 0.000 \\
\hline \multirow{6}{*}{ Pressing time } & $\begin{array}{l}\text { Density } \\
\left(\mathrm{kg} / \mathrm{m}^{3}\right)\end{array}$ & $44,648.253$ & 3 & $14,882.751$ & 2.285 & 0.083 \\
\hline & TS 24 h (\%) & 421.488 & 3 & 140.496 & 0.496 & 0.686 \\
\hline & WA 24 h (\%) & 1060.883 & 3 & 353.628 & 0.708 & 0.549 \\
\hline & $\operatorname{MOR}\left(\mathrm{N} / \mathrm{mm}^{2}\right)$ & 1081.134 & 3 & 360.378 & 13.461 & 0.000 \\
\hline & $\operatorname{MOE}\left(\mathrm{N} / \mathrm{mm}^{2}\right)$ & $2.348 \times 10^{7}$ & 3 & $7.827 \times 10^{6}$ & 14.943 & 0.000 \\
\hline & $\mathrm{IB}\left(\mathrm{N} / \mathrm{mm}^{2}\right)$ & 0.995 & 3 & 0.332 & 3.771 & 0.013 \\
\hline
\end{tabular}


Table 4. Cont.

\begin{tabular}{|c|c|c|c|c|c|c|}
\hline Factor & Properties & $\begin{array}{l}\text { Sum of } \\
\text { Squares }\end{array}$ & d.f. & Half Quadratic & $\mathbf{F}$ & Sig \\
\hline \multirow{6}{*}{ Starch (\%) } & $\begin{array}{l}\text { Density } \\
\left(\mathrm{kg} / \mathrm{m}^{3}\right)\end{array}$ & $225,752.148$ & 2 & $112,876.074$ & 24.920 & 0.000 \\
\hline & TS 24 h $(\%)$ & $22,366.496$ & 2 & $11,183.248$ & 170.680 & 0.000 \\
\hline & WA 24 h (\%) & $28,956.715$ & 2 & $14,478.357$ & 71.060 & 0.000 \\
\hline & $\operatorname{MOR}\left(\mathrm{N} / \mathrm{mm}^{2}\right)$ & 1686.149 & 2 & 843.074 & 40.973 & 0.000 \\
\hline & $\operatorname{MOE}\left(\mathrm{N} / \mathrm{mm}^{2}\right)$ & $14,861,771.141$ & 2 & $7,430,885.571$ & 12.256 & 0.000 \\
\hline & $\mathrm{IB}\left(\mathrm{N} / \mathrm{mm}^{2}\right)$ & 3.682 & 2 & 1.841 & 50.932 & 0.000 \\
\hline \multirow{6}{*}{ Cement (\%) } & $\begin{array}{l}\text { Density } \\
\left(\mathrm{kg} / \mathrm{m}^{3}\right)\end{array}$ & 7589.261 & 1 & 7589.261 & 1.391 & 0.243 \\
\hline & TS 24 h (\%) & 80.590 & 1 & 80.590 & 7.165 & 0.010 \\
\hline & WA 24 h (\%) & 1418.878 & 1 & 1418.878 & 5.653 & 0.021 \\
\hline & $\operatorname{MOR}\left(\mathrm{N} / \mathrm{mm}^{2}\right)$ & 307.374 & 1 & 307.374 & 15.118 & 0.000 \\
\hline & $\operatorname{MOE}\left(\mathrm{N} / \mathrm{mm}^{2}\right)$ & $8,513,888.803$ & 1 & $8,513,888.803$ & 12.613 & 0.001 \\
\hline & $\mathrm{IB}\left(\mathrm{N} / \mathrm{mm}^{2}\right)$ & 0.773 & 1 & 0.773 & 16.647 & 0.000 \\
\hline
\end{tabular}

d.f.: degrees of freedom. F: Fisher-Snedecor distribution. Sig: significance.

\subsection{SEM Observations}

Scanning electron microscope (SEM) observations were made to investigate the interaction between the three components of the experimental boards. Using a standard method [78], the mineralogical evolution of cement during hydration of the boards was analyzed. Micrographs were obtained at 8 and 28 days after the manufacture of the boards of class 2, which contained $20 \%$ cement and 10\% starch and had been pressed for $2 \mathrm{~h}$. Samples for SEM were polished and plated with gold.

Figure 8a shows that starch has gelled and enveloped the cement grains that were being hydrated. Figure $8 \mathrm{~b}$ shows how cement grains were hydrating eight days after panels were made. It can be differentiated that alite (calcium silicate) and belite (dicalcium silicate) were hydrating, forming tobermorite grains. Hydration cracks were also found.

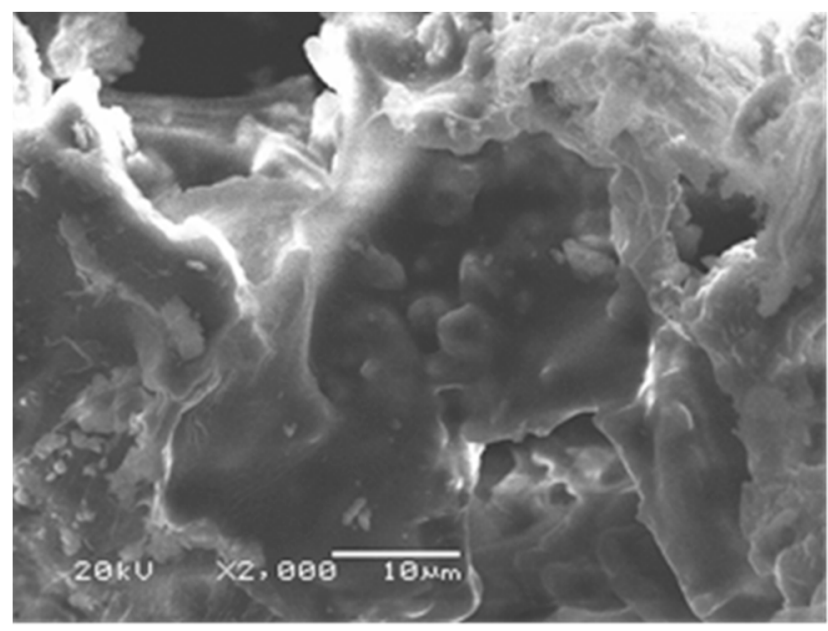

(a)

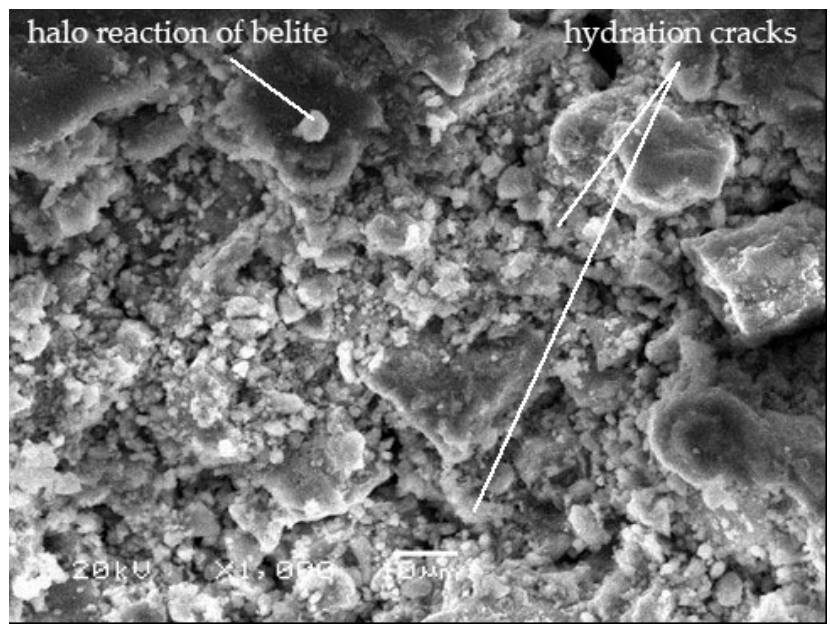

(b)

Figure 8. (a) Starch gel enveloping cement grains 3 days after hydration and (b) cement grains 8 days after hydration.

Figure 9a shows a cube of gypsum (calcium sulfate) that was added to the clinker to decrease the solubility of the aluminate. This cube is surrounded by crystals of tricalcium silicate $\left(\mathrm{C}_{3} \mathrm{~S}\right)$ transformed into tobermorite gel (hydrated calcium silicates), whose grains began to coalesce. In Figure 9b, tobermorite is seen over an organic gel, indicating that the starch has gelled. 


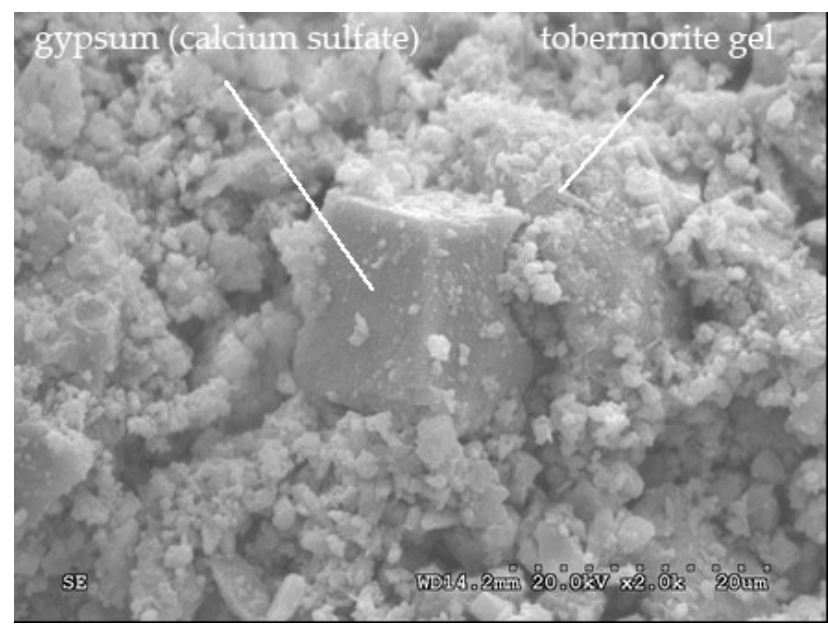

(a)

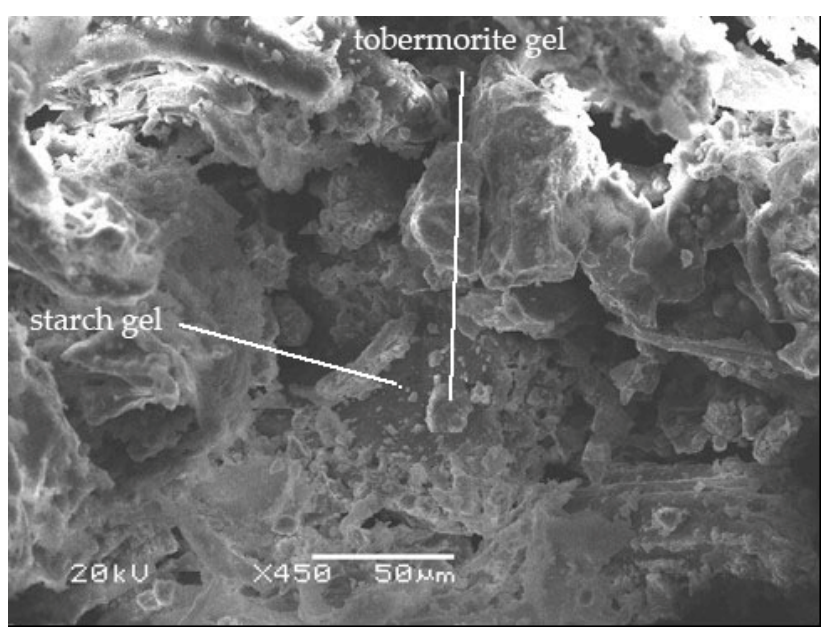

(b)

Figure 9. (a) Gypsum cube surrounded by tobermorite gel 3 days after hydration and (b) tobermorite over an organic gel 8 days after hydration.

Figure 10a shows that tobermorite gel has bonded, forming a continuous matrix, while in Figure 10b some tobermorite grains have coalesced forming a continuous layered matrix. Some thin hexagonal plates can be seen, indicating the presence of portlandite $\left[\mathrm{Ca}(\mathrm{OH})_{2}\right]$.

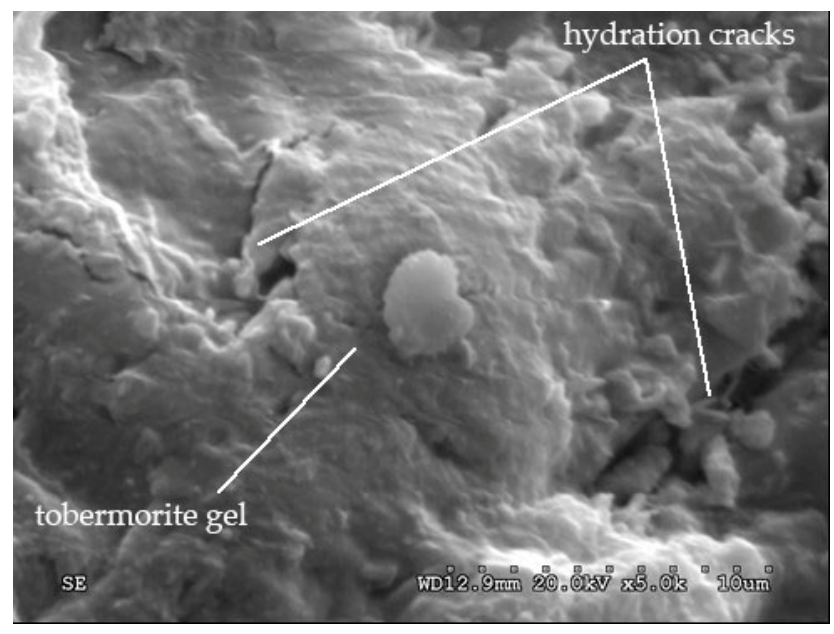

(a)

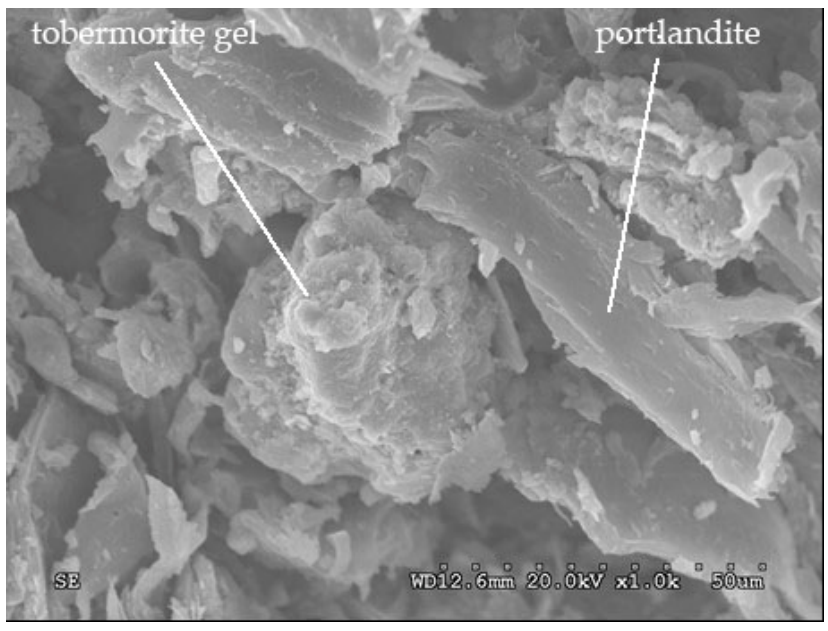

(b)

Figure 10. (a) Tobermorite gel 8 days after hydration and (b) tobermorite and crystalized portlandite 8 days after hydration.

Figure 11a shows the halo reaction of belite (dicalcium silicate). In Figure 11b, alite crystals (calcium silicate) in the hydration process are seen, forming tobermorite grains which were forming a gel. 


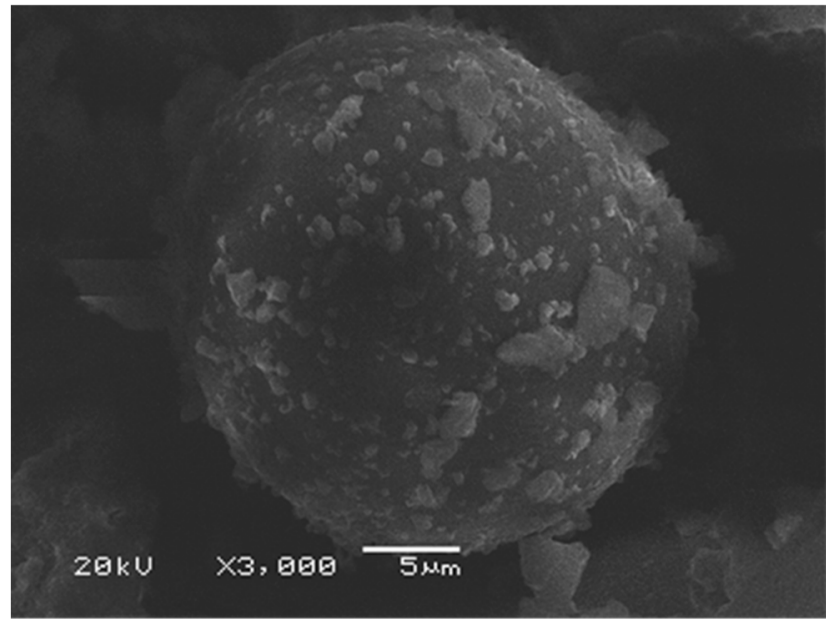

(a)

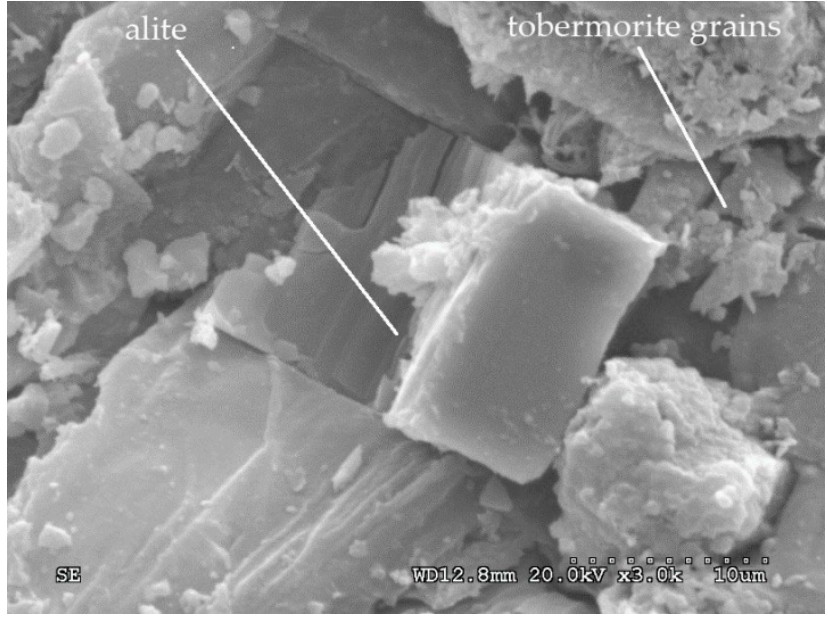

(b)

Figure 11. (a) Belite 8 days after hydration and (b) tobermorite, alite and portlandite 8 days after hydration.

Portlandite (calcium hydroxide) over tobermorite (hydrated calcium silicates) is observed in Figure 12a, with no ettringite found. Figure $12 \mathrm{~b}$ shows giant reed fibers glued together, with no degradation due to the alkalinity of the cement observed.

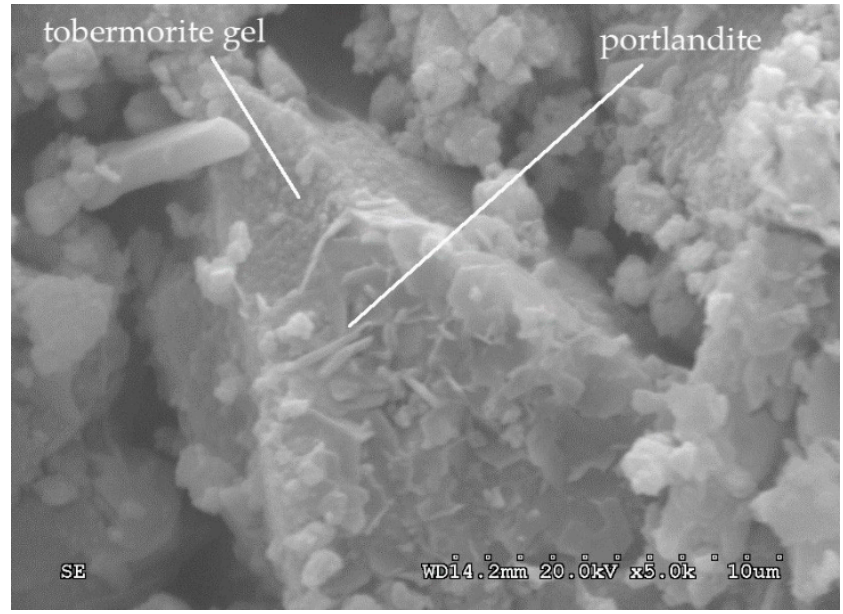

(a)

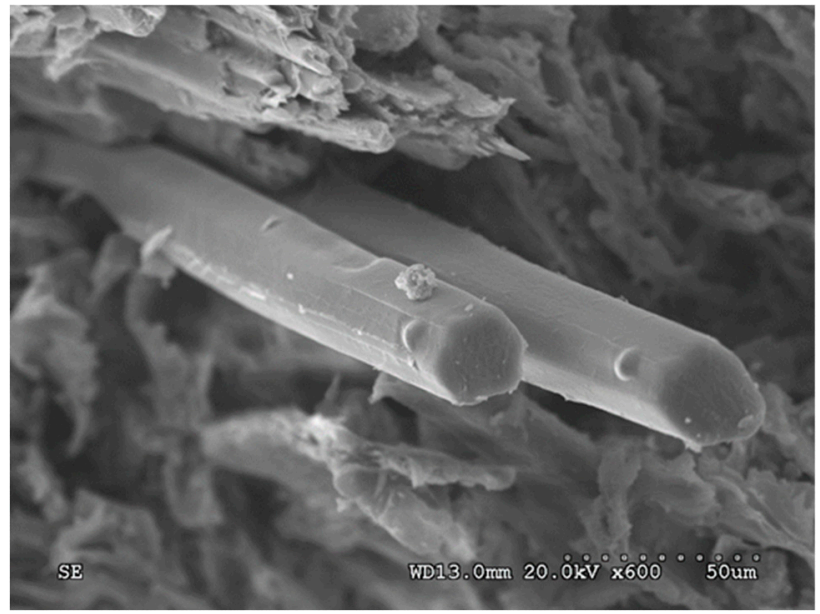

(b)

Figure 12. (a) Portlandite over tobermorite 8 days after hydration and (b) giant reed fibers 8 days after hydration.

There is no visible sign of microcracks on the surface of the boards 8 or 28 days after setting in Figure 13. Even though other authors observed degradation of plant fibers in contact with cement by alkaline hydrolysis, the hydration process of the experimental boards of this study was optimal. 


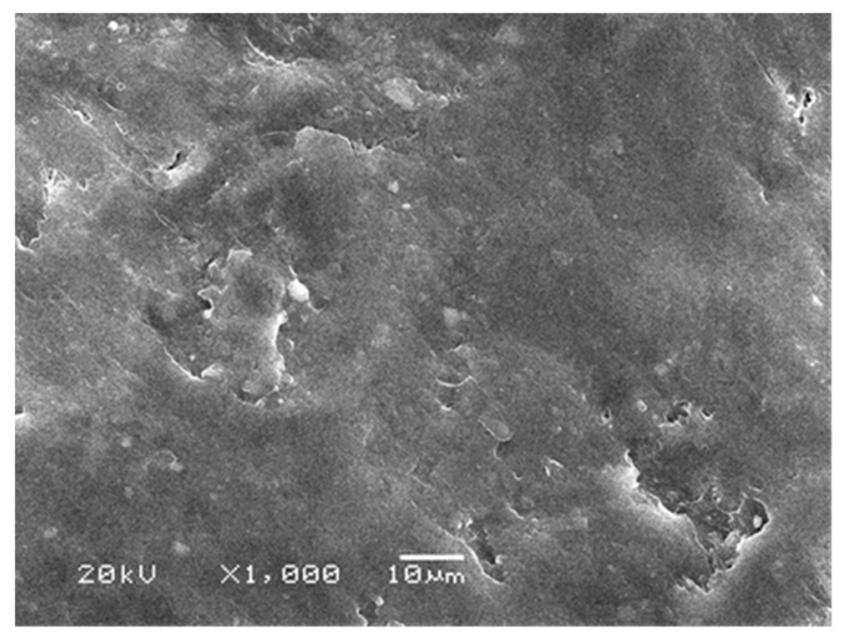

(a)

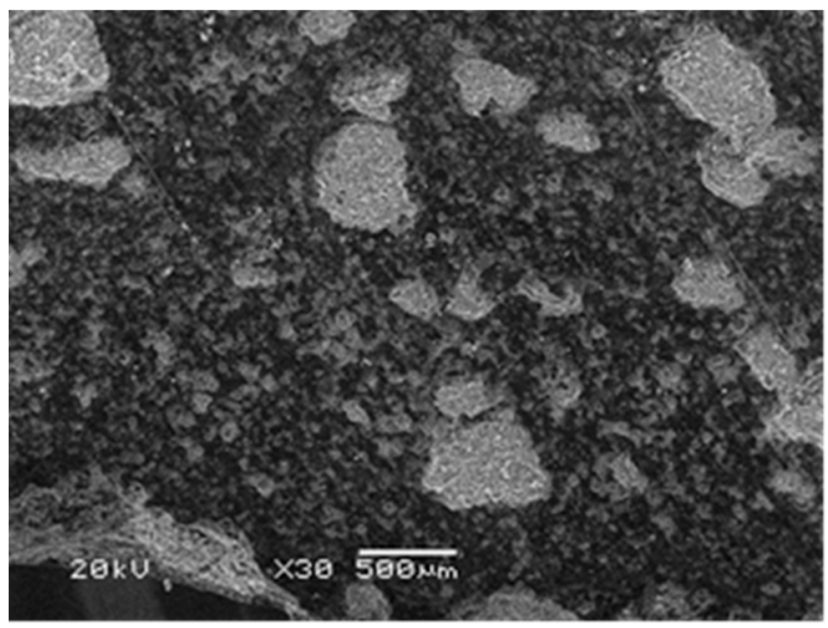

(b)

Figure 13. Surface of the board (a) 8 days after hydration and (b) 28 days after hydration.

To elucidate the mechanism involved in why boards with starch (types A, B and C) have better properties than boards without starch (D and E), a micrograph of board type E2 (no starch, 20\% cement and $2 \mathrm{~h}$ in the press) after 28 days of setting is shown in Figure 14.

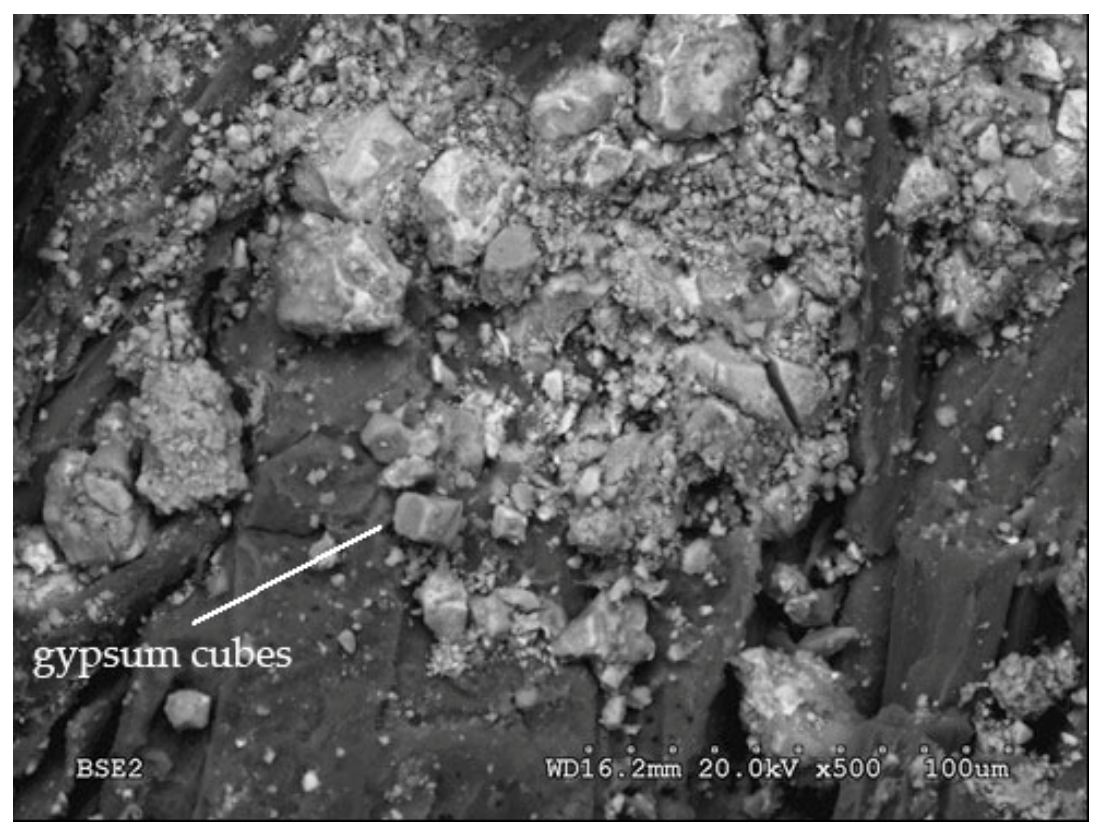

Figure 14. Cross-sectional micrograph of a board type E2 28 days after hydration.

It shows cement components without hydration. This indicates that there was a water shortage that prevented a correct absorption of water by the cement. It is possible that water contained in the mixture before hot pressing was attracted by the reed particles and then evaporated when pressed. Boards made with starch could have retained this water and later released it to the cement to hydrate it properly, thereby improving the mechanical performance of the board.

\section{Discussion}

Particleboards are classified based on their mechanical properties and dimensional stability by European Standards [68], which establishes minimum requirements of their properties. Their grades range from P1 to P7 (Table 5). 
Table 5. Classification of experimental panels based on European Standards [68].

\begin{tabular}{cl}
\hline Grade & \multicolumn{1}{c}{ Definition } \\
\hline P1 & Boards for general use in dry conditions \\
\hline P2 & $\begin{array}{l}\text { Boards for indoor application (including furniture) in dry } \\
\text { conditions }\end{array}$ \\
\hline P3 & Non-structural boards for use in humid conditions \\
\hline P4 & Structural boards for use in dry conditions \\
\hline P5 & Structural boards for use in humid conditions \\
\hline P6 & High performance structural boards for use in dry conditions \\
\hline P7 & High performance structural boards for use in humid conditions \\
\hline
\end{tabular}

According to Table 6, boards whose only binder was 20\% cement (type E) had lower mechanical properties, which indicates that hydration of the cement was not adequate and the water initially contained in the mixture was absorbed by the giant reed particles. When pressure and heat were applied to these boards, water evaporated, preventing the correct setting of the cement.

Table 6. Physical and mechanical properties of the experimental panels.

\begin{tabular}{|c|c|c|c|c|c|}
\hline Type of Panel & $\begin{array}{c}\text { Classification EN } \\
312[68]\end{array}$ & $\operatorname{MOR}\left(\mathrm{N} / \mathrm{mm}^{2}\right)$ & $\operatorname{MOE}\left(\mathrm{N} / \mathrm{mm}^{2}\right)$ & IB $\left(\mathrm{N} / \mathrm{mm}^{2}\right)$ & TS 24 h (\%) \\
\hline A1 & $\mathrm{P} 2$ & $12.89(1.44)$ & $1846.04(368.20)$ & $0.41(0.13)$ & $15.54(3.37)$ \\
\hline A2 & P3 & $15.98(1.19)$ & $2083.50(335.15)$ & $0.53(0.22)$ & $11.12(2.85)$ \\
\hline A3 & $\mathrm{P} 4$ & $19.79(3.06)$ & $2636.88(521.43)$ & $0.66(0.27)$ & $13.33(3.08)$ \\
\hline $\mathrm{A} 4$ & P6 & $26.11(2.28)$ & 3759.76 (377.99) & $0.76(0.21)$ & $12.38(1.35)$ \\
\hline B1 & P1 & $13.33(1.13)$ & $2130.78(304.21)$ & $0.34(0.15)$ & $13.96(5.22)$ \\
\hline B2 & $\mathrm{P} 2$ & $14.19(1.63)$ & $2610.01(520.34)$ & $0.42(0.23)$ & $13.48(3.28)$ \\
\hline B3 & $\mathrm{P} 4$ & $16.94(1.49)$ & $2392.63(488.00)$ & $0.79(0.21)$ & $15.25(5.77)$ \\
\hline B4 & $\mathrm{P} 4$ & $19.88(0.91)$ & 3076.93 (431.62) & $0.74(0.14)$ & 13.49 (1.59) \\
\hline $\mathrm{C} 1$ & P2 & $12.56(6.07)$ & 2021.89 (461.01) & $0.54(0.19)$ & $24.22(8.13)$ \\
\hline $\mathrm{C} 2$ & P3 & $20.76(2.51)$ & $3058.56(389.95)$ & $0.71(0.09)$ & $16.83(3.09)$ \\
\hline $\mathrm{C} 3$ & P3 & $21.60(1.60)$ & 3104.68 (541.19) & $0.84(0.24)$ & $16.95(2.75)$ \\
\hline $\mathrm{C} 4$ & P6 & $27.26(3.29)$ & $4287.44(554.31)$ & $0.95(0.33)$ & $14.04(1.03)$ \\
\hline D1 & $\mathrm{P} 1$ & $11.41(0.81)$ & $2325.87(211.76)$ & $0.31(0.01)$ & $58.50(14.50)$ \\
\hline D2 & $\mathrm{P} 1$ & $12.72(0.46)$ & $2426.60(356.39)$ & $0.31(0.04)$ & $49.42(0.17)$ \\
\hline D3 & P1 & $13.82(1.44)$ & $2519.48(198.45)$ & $0.34(0.03)$ & $44.83(16.6)$ \\
\hline $\mathrm{D} 4$ & P1 & $18.04(0.35)$ & 3080.12 (126.14) & $0.36(0.10)$ & $50.41(11.20)$ \\
\hline E1 & - & $6.22(0.22)$ & $1234.77(131.71)$ & $0.16(0.11)$ & $42.24(1.56)$ \\
\hline E2 & - & $6.40(0.24)$ & $1426.89(167.47)$ & $0.16(0.06)$ & $36.79(3.71)$ \\
\hline E3 & - & $8.71(0.34)$ & $1713.74(11.04)$ & $0.33(0.10)$ & $37.79(7.15)$ \\
\hline $\mathrm{E} 4$ & - & $9.45(1.02)$ & $1865.42(64.53)$ & $0.21(0.09)$ & $26.73(6.59)$ \\
\hline $\mathrm{F} 1$ & - & $9.90(0.30)$ & $1958.16(71.76)$ & $0.27(0.01)$ & $37.28(1.85)$ \\
\hline $\mathrm{F} 2$ & - & $7.90(0.47)$ & $1663.29(1.38)$ & $0.28(0.02)$ & $39.89(0.67)$ \\
\hline F3 & - & $9.46(0.43)$ & $1784.03(37.78)$ & $0.21(0.01)$ & $49.11(0.71)$ \\
\hline $\mathrm{F} 4$ & - & $12.06(0.29)$ & $2443.87(51.51)$ & $0.27(0.01)$ & $56.34(0.71)$ \\
\hline G1 & P1 & $13.00(0.07)$ & $2148.25(70.71)$ & $0.30(0.01)$ & $41.41(1.41)$ \\
\hline $\mathrm{G} 2$ & $\mathrm{P} 1$ & $14.04(0.27)$ & 2192.85 (95.95) & $0.28(0.01)$ & $43.44(1.59)$ \\
\hline G3 & $\mathrm{P} 1$ & $15.63(0.48)$ & $2211.76(119.50)$ & $0.28(0.01)$ & $48.49(1.52)$ \\
\hline G4 & $\mathrm{P} 1$ & $18.53(0.69)$ & $2763.68(72.18)$ & $0.29(0.01)$ & $46.18(2.28)$ \\
\hline
\end{tabular}


Table 6. Cont.

\begin{tabular}{|c|c|c|c|c|c|}
\hline Type of Panel & $\begin{array}{c}\text { Classification EN } \\
312[68]\end{array}$ & $\operatorname{MOR}\left(\mathrm{N} / \mathrm{mm}^{2}\right)$ & $\operatorname{MOE}\left(\mathrm{N} / \mathrm{mm}^{2}\right)$ & IB $\left(\mathrm{N} / \mathrm{mm}^{2}\right)$ & TS 24 h (\%) \\
\hline \multirow{3}{*}{$\begin{array}{l}\text { Thickness } \\
\text { 6-13 mm [68] }\end{array}$} & $\mathrm{P} 1$ & 10.50 & - & 0.28 & - \\
\hline & P2 & 11.00 & 1800.00 & 0.40 & - \\
\hline & P3 & 15.00 & 2050.00 & 0.45 & 17.00 \\
\hline \multirow{4}{*}{$\begin{array}{l}\text { 1hickness } \\
\text { 6-10 mm [68] }\end{array}$} & $\mathrm{P} 4$ & 16.00 & 2300.00 & 0.40 & 16.00 \\
\hline & P5 & 18.00 & 2550.00 & 0.45 & 13.00 \\
\hline & P6 & 20.00 & 3150.00 & 0.60 & 16.00 \\
\hline & P7 & 22.00 & 3350.00 & 0.75 & 10.00 \\
\hline
\end{tabular}

() standard deviation.

The boards with the best performance were types A4 and C4, which met European Standards [68] and could be classified as P6 (high performance structural load-bearing particleboard to use in dry conditions). In general, boards with the best properties are those in which a mixture of cement and starch has been used as a binder.

Higher proportions of cement produced lower TH, whereas higher proportions of starch resulted in better mechanical performances. Starch could have retained part of the water previously added onto the mixture to later transfer it to the cement, favoring its correct hydration. This confirmed a study that suggested that in order to improve the properties of cementitious compounds, an additive of cellulose and starch was added because it behaves as a good water-retention agent [62].

The two manufacturing variables considered in this study were the type of binder and the time in the hot plate press. The type of binder is the most influential parameter since all physical and mechanical properties varied according to it (density, TS, WA MOR, MOE and IB). The pressing time affected half of the properties tested (MOR, MOE and IB).

Several authors noticed that during the setting time of cement composites with plant fibers, there was a delay in the formation of hydration products $[15,28,79]$. They attributed it to different fiber components, especially sugars. A different study indicated that pectins contained in the jute fibers combined with the cement functioned as a growth inhibitor of calcium silicate hydrate (CSH) [41].

SEM micrographs showed calcium compounds at eight days of setting and therefore the hydration process had not been delayed. In addition, micrographs showed how the gelled starch enveloped the cement grains, which would make difficult its dilution and the interaction of the reed components with the cement.

The hydration of the cement in the experimental boards is in accordance with the study carried out with cement without plant fibers at seven days [78]. Some research [57] affirms that plant fibers degrade in contact with cement by alkaline hydrolysis. However, in this work, no signs of degradation of giant reed fibers were observed at 28 days. Another investigation [31] indicated that composites made of cement and plant fibers decrease performance in MOR and MOE after one year of setting due to carbonation of the matrix followed by lixiviation and progressive microcracking. In this paper, results appear to differ, with the MOR and MOE behavior of the panels even increasing, indicating that there was no incompatibility between the three components (giant reed, cement and starch).

Other researchers obtained composites made of cement and wood or plant fibers. Their results are shown in Table 7. Pine wood-cement composites have lower performance than the boards of this study. It is possible that this type of wood requires large amounts of cement to comply with European Standards [68]. With eucalypt and rubberwood or with pretreated coconut coir, the results of TS are better than in this study. Nonetheless, one of the uses of these composites is in humid conditions such as terraces or façades. It is possible that the pretreatment of the coconut or the amount of cement could improve the TS of the panels of this study. The behavior of canary palm composites with amounts of cement similar to this investigation is sufficient to be commercialized as P2 [68]. However, their properties are behind the giant reed-cement composites of this study. 
Table 7. Properties obtained with cement composites.

\begin{tabular}{|c|c|c|c|c|c|c|}
\hline Source & Material & $\begin{array}{c}\text { Ratio Ce- } \\
\text { ment/Material }\end{array}$ & $\begin{array}{c}\text { MOR } \\
\left(\mathrm{N} / \mathrm{mm}^{2}\right)\end{array}$ & $\begin{array}{c}\text { MOE } \\
\left(\mathrm{N} / \mathrm{mm}^{2}\right)\end{array}$ & $\begin{array}{c}\text { IB } \\
\left(\mathrm{N} / \mathrm{mm}^{2}\right)\end{array}$ & $\begin{array}{c}\text { TS } 24 \text { h } \\
(\%)\end{array}$ \\
\hline [5] & Pine & $3 / 1$ & 15.8 & 5495 & - & 18.5 \\
\hline [9] & $\begin{array}{c}50 \% \text { Eucalypt } \\
\text { and } 50 \% \\
\text { rubberwood }\end{array}$ & $8 / 1$ & 6.40 & 4090 & 0.34 & 1.80 \\
\hline [21] & Coconut coir & $2 / 1$ & 19.94 & 5315 & 0.73 & 3.64 \\
\hline [37] & Canary palm & $1 / 5$ & 15.76 & 1872 & 0.68 & 26.70 \\
\hline $\begin{array}{l}\text { This work } \\
\text { (C4) }\end{array}$ & Giant reed & $1 / 10$ & 27.26 & 4287.44 & 0.95 & 14.04 \\
\hline
\end{tabular}

Industrial boards are normally manufactured with a wood/cement ratio of $1 / 5.5$. The boards in this work have been made with a small amount of cement, with the ratio in weight of giant reed/cement being 1/0.2 maximum. Pressing time was a maximum of $4 \mathrm{~h}$ at $100{ }^{\circ} \mathrm{C}$, while industrial boards need $8 \mathrm{~h}$ at $75^{\circ} \mathrm{C}$ and drying times of $8 \mathrm{~h}$ at $90^{\circ} \mathrm{C}$. The experimental boards described in this study have been made with less time and with a much lower proportion of cement than in the production of industrial wood-cement boards. This represents significant energy savings in their manufacture and makes them potentially a more ecological product.

\section{Conclusions}

The effects of the binder (starch-cement) on the physical and mechanical properties of boards made of giant reed (Arundo donax L.) particles were investigated.

High-quality sustainable particleboards (boards with high structural performance) were obtained using giant reed and can be classified as P6 according to European Standards. Mechanical properties were improved by increasing the starch content, whereas greater resistance to water was obtained by increasing the cement content.

The pressing time of the boards in the hot plate press at $100{ }^{\circ} \mathrm{C}$ had a great influence in MOR, MOE and IB, which increased performance. Further tests are needed to determine the optimum pressing temperature and time for the manufacturing process.

Cement is mineralized in the giant reed-cement-starch particleboards following the same hydration process that occurred without fibers or additives. Giant reed particles seem to tolerate the alkalinity of the cement since there was no sign of degradation of its fibers, with MOR and MOE even increasing at 365 days of setting.

Using giant reed particles, cementitious composites can be made which could be used in the manufacture of various construction components. Therefore, the use of these residues in the manufacture of construction materials offers a very attractive alternative in terms of price, technology and sustainability.

Author Contributions: Idea and methodology, A.A.F.-G. and M.T.F.-G.; Experiments, M.T.F.-G. and A.A.F.-G.; Resources, T.G.O.; Statistics, M.F.-V. and A.F.-G.; Project administration, A.F.-G.; Supervision, M.F.-V.; Writing, A.A.F.-G. and A.F.-G.; Review, T.G.O. All authors have read and agreed to the published version of the manuscript.

Funding: This research was funded thanks to Agreement No. 4/20 between the company Aitana, Actividades de Construcciones y Servicios, S.L., and Universidad Miguel Hernandez, Elche.

Institutional Review Board Statement: Not applicable.

Informed Consent Statement: Not applicable.

Data Availability Statement: The data presented in this study are available within the article.

Acknowledgments: The authors would like to thank the company Aitana, Actividades de Construcciones y Servicios, S.L., for its support by signing Agreement No. 4/20 with Universidad Miguel Hernández, Elche, on 20 December 2019.

Conflicts of Interest: The authors declare no conflict of interest. 


\section{References}

1. Directive 2008/98/EC of The European Parliament and of The Council on Waste and Repealing Certain Directives. Off. J. Eur. Union 2008, L312, 3-30, Current consolidated version: 5 July 2018.

2. Directive 2010/75/EU of the European Parliament and of the Council of 24 November 2010 on industrial emissions (integrated pollution prevention and control). Off. J. Eur. Union 2010, L334, 159-261, Current consolidated version: 6 January 2011.

3. Directive (EU) 2018/850 of the European Parliament and of the Council of 30 May 2018 amending Directive 1999/31/EC on the landfill of waste. Off. J. Eur. Union 2018, L150, 100-108.

4. Regulation (EU) 2018/841 of the European Parliament and of the Council of 30 May 2018 on the inclusion of greenhouse gas emissions and removals from land use, land use change and forestry in the 2030 climate and energy framework, and amending Regulation (EU) No 525/2013 and Decision No 529/2013/EU. Off. J. Eur. Union 2018, L156, 1-25.

5. Moslemi, A.A.; Pfister, S.C. The influence of cement/wood ratio and cement type on bending strength and dimensional stability of wood-cement composite panels. Wood Fiber Sci. 1987, 19, 165-175.

6. Ferrier, E.; Agbossou, A.; Michel, L. Mechanical behaviour of ultra-high-performance fibrous-concrete wood panels reinforced by FRP bars. Compos. Part B Eng. 2014, 60, 663-672. [CrossRef]

7. Li, M.; Khelifa, M.; Khennane, A.; El Ganaoui, M. Structural response of cement-bonded wood composite panels as permanent formwork. Compos. Struct. 2019, 209, 13-22. [CrossRef]

8. Brahmia, F.Z.; Horváth, P.G.; Alpár, T.L. Effect of pre-treatments and additives on the improvement of cement wood composite: A review. BioResources 2020, 15, 7288-7308. [CrossRef]

9. Okino, E.Y.; De Souza, M.R.; Santana, M.A.; da S Alves, M.V.; de Sousa, M.E.; Teixeira, D.E. Cement-bonded wood particleboard with a mixture of eucalypt and rubberwood. Cem. Concr. Compos. 2004, 26, 729-734. [CrossRef]

10. Tittelein, P.; Cloutier, A.; Bissonnette, B. Design of a low-density wood-cement particleboard for interior wall finish. Cem. Concr. Compos. 2012, 34, 218-222. [CrossRef]

11. Fuwape, J.A.; Oyagade, A.O. Bending strength and dimensional stability of tropical wood-cement particleboard. Bioresour. Technol. 1993, 44, 77-79. [CrossRef]

12. Karade, S.R. Cement-bonded composites from lignocellulosic wastes. Constr. Build. Mater. 2010, 24, 1323-1330. [CrossRef]

13. Ashori, A.; Tabarsa, T.; Valizadeh, I. Fiber reinforced cement boards made from recycled newsprint paper. Mater. Sci. Eng. A 2011, 528, 7801-7804. [CrossRef]

14. Olorunnisola, A.O.; Adefisan, O.O. Trial production and testing of cement-bonded particleboard from rattan furniture waste. Wood Fiber Sci. 2002, 34, 116-124.

15. Sudin, R.; Swamy, N. Bamboo and wood fibre cement composites for sustainable infrastructure regeneration. J. Mater. Sci. 2006, 41, 6917-6924. [CrossRef]

16. Torkaman, J.; Ashori, A.; Momtazi, A.S. Using wood fiber waste, rice husk ash, and limestone powder waste as cement replacement materials for lightweight concrete blocks. Constr. Build. Mater. 2014, 50, 432-436. [CrossRef]

17. Wei, J.; Meyer, C. Sisal fiber-reinforced cement composite with Portland cement substitution by a combination of metakaolin and nanoclay. J. Mater. Sci. 2014, 49, 7604-7619. [CrossRef]

18. Frazão, C.; Barros, J.; Toledo Filho, R.; Ferreira, S.; Gonçalves, D. Development of sandwich panels combining sisal fiber-cement composites and fiber-reinforced lightweight. Concr. Cem. Concr. Comp. 2018, 86, 206-223. [CrossRef]

19. Thomas, B.C.; Jose, Y.S. Impact of sisal fiber reinforced concrete and its performance analysis: A review. Evolut. Intell. 2019, 1-11. [CrossRef]

20. Aggarwal, L.K. Studies on cement bonded coir fibre boards. Cem. Concr. Compos. 1992, 14, 63-69. [CrossRef]

21. Asasutjarit, C.; Hirunlabh, J.; Khedari, J.; Charoenvai, S.; Zeghmati, B.; Cheul Shin, U. Development of coconut coir-based lightweight cement board. Constr. Build. Mater. 2007, 21, 277-288. [CrossRef]

22. Silva, F.A.; Toledo Filho, R.D.; Melo Filho, J.A.; Fairbairn, E.M.R. Physical and mechanical properties of durable sisal fiber-cement composites. Constr. Build. Mater. 2010, 24, 777-785. [CrossRef]

23. Wang, W.; Chouw, N. The behaviour of coconut fibre reinforced concrete (CFRC) under impact loading. Constr. Build. Mater. 2017, 134, 452-461. [CrossRef]

24. Da Silva, E.J.; Marques, M.L.; Velasco, F.G.; Junior, C.F.; Luzardo, F.M.; Tashima, M.M. A new treatment for coconut fibers to improve the properties of cement-based composites-Combined effect of natural latex/pozzolanic materials. Sustain. Mater. Technol. 2017, 12, 44-51. [CrossRef]

25. Sathiparan, N.; Rupasinghe, M.N.; Pavithra, B.H. Performance of coconut coir reinforced hydraulic cement mortar for surface plastering application. Constr. Build. Mater. 2017, 142, 23-30. [CrossRef]

26. Farias Machado, N.A.; Barros Furtado, M.; Parra-Serrano, L.J.; de Oliveira Maia Parente, M.; Fiorelli, J.; Savastano Júnior, H. Agglomerated panels made from babaçu coconut residues. Rev. Bras. Cienc. Agrár. 2017, 12, 202-209. [CrossRef]

27. Aggarwal, L.K. Bagasse-reinforced cement composites. Cem. Concr. Compos. 1995, 17, 107-112. [CrossRef]

28. Bilba, K.; Arsène, M.A.; Ouensanga, A. Sugar cane bagasse fibre reinforcedcement composites. Part, I. Influence of the botanical components of bagasse on the setting of bagasse/cement composite. Cem. Concr. Compos. 2003, 25, 91-96. [CrossRef]

29. Cabral, M.R.; Nakanishi, E.Y.; Dos Santos, V.; Palacios, J.H.; Godbout, S.; Junior, H.S.; Fiorelli, J. Evaluation of pre-treatment efficiency on sugarcane bagasse fibers for the production of cement composites. Arch. Civ. Mech. Eng. 2018, 18, 1092-1102. [CrossRef] 
30. Almeida, R.R.; Del Menezzi, C.H.S.; Teixeira, D.E. Utilization of the coconut shell of babaçu (Orbignya sp.) to produce cementbonded particleboard. Bioresour. Technol. 2002, 85, 159-163. [CrossRef]

31. Savastano, H., Jr.; Warden, P.G.; Coutts, R.S. Potential of alternative fibre cements as building materials for developing areas. Cem. Concr. Compos. 2003, 25, 585-592. [CrossRef]

32. Teixeira, J.N.; Silva, D.W.; Vilela, A.P.; Junior, H.S.; de Siqueira Brandão, L.E.V.; Mendes, R.F. Lignocellulosic materials for fiber cement production. Waste Biomass Valoriz. 2020, 11, 2193-2200. [CrossRef]

33. Cabalo, V.B. Utilization of coconut coir and abaca stripping waste fibers for cement bonded board. J. Sci. Eng. Technol. 2015, 3, 183-188.

34. Basri, H.B.; Mannan, M.A.; Zain, M.F.M. Concrete using waste oil palm shells as aggregate. Cem. Concr. Res. 1999, $29,619-622$. [CrossRef]

35. Hermawan, D.; Subiyanto, B.; Kawai, S. Manufacture and properties of oil palm frond cement-bonded board. J. Wood Sci. 2001, 47, 208-213. [CrossRef]

36. Mannan, M.A.; Alexander, J.; Ganapathy, C.; Teo, D.C.L. Quality improvement of oil palm shell (OPS) as coarse aggregate in lightweight concrete. Build. Environ. 2006, 41, 1239-1242. [CrossRef]

37. Ferrandez-Villena, M.; Ferrandez-Garcia, C.E.; Garcia-Ortuño, T.; Ferrandez-Garcia, A.; Ferrandez-Garcia, M.T. Properties of cement-bonded particleboards made from Canary Islands palm (Phoenix canariensis Ch.) trunks and different amounts of potato starch. Forests 2020, 11, 560. [CrossRef]

38. Aggarwal, L.K.; Agrawal, S.P.; Thapliyal, P.C.; Karade, S.R. Cement-bonded composite boards with arhar stalks. Cem. Concr. Compos. 2008, 30, 44-51. [CrossRef]

39. Juarez, C.; Duran, A.; Valdez, P.; Fajardo, G. Performance of "Agave lecheguilla" natural fiber in Portland cement composites exposed to severe environment conditions. Build. Environ. 2007, 42, 1151-1157. [CrossRef]

40. Kriker, A.; Bali, A.; Debicki, G.; Bouziane, M.; Chabannet, M. Durability of date palm fibres and their use as reinforcement in hot dry climates. Cem. Concr. Compos. 2008, 30, 639-648. [CrossRef]

41. Sedan, D.; Pagnoux, C.; Smith, A.; Chotard, T. Mechanical properties of hemp fibre reinforced cement: Influence of the fibre/matrix interaction. J. Eur. Ceram. Soc. 2008, 28, 183-192. [CrossRef]

42. Diquélou, Y.; Gourlay, E.; Arnaud, L.; Kurek, B. Impact of hemp shiv on cement setting and hardening: Influence of the extracted components from the aggregates and study of the interfaces with the inorganic matrix. Cem. Concr. Compos. 2015, 55, 112-121. [CrossRef]

43. Çomak, B.; Bideci, A.; Bideci, Ö.S. Effects of hemp fibers on characteristics of cement based mortar. Constr. Build. Mater. 2018, 169, 794-799. [CrossRef]

44. Nguyen-Sy, T.; Tran-Le, A.D.; Nguyen-Thoi, T.; Langlet, T. A multi-scale homogenization approach for the effective thermal conductivity of dry lime-hemp concrete. J. Build. Perform. Simul. 2018, 11, 179-189. [CrossRef]

45. Fernea, R.; Manea, D.L.; Plesa, L.; Iernuțan, R.; Dumitran, M. Acoustic and thermal properties of hemp-cement building materials. Procedia Manuf. 2019, 32, 208-215. [CrossRef]

46. Mahjoub, R.; Yatim, J.M.; Mohd Sam, A.R.; Hashemi, S.H. Tensile properties of kenaf fiber due to various conditions of chemical fiber surface modifications. Constr. Build. Mater. 2014, 55, 103-113. [CrossRef]

47. Ferrández-García, C.E.; García-Ortuño, T.; Andreu-Rodríguez, J.; Ferrández-Villena, M.; Ferrández-García, M.T. Mechanical properties of a cement mortar reinforced with Arundo donax L. reeds. Int. J. Civ. Eng. 2015, 2, 305-308.

48. Demirbas, A.; Aslan, A. Effects of ground hazelnut shell, wood and tea waste on the mechanical properties of cement. Cem. Concr. Res. 1998, 28, 1101-1104. [CrossRef]

49. Karade, S.R.; Irle, M.A.; Maher, K. Influence of granule properties and concentration on cork-cement compatibility. HolzRohWerkst 2006, 64, 281-286. [CrossRef]

50. Ferrandez-García, M.T.; Ferrandez-Garcia, C.E.; Garcia-Ortuño, T.; Ferrandez-Garcia, A.; Ferrandez-Villena, M. Study of waste jute fibre panels (corchorus capsularis L.) agglomerated with Portland cement and starch. Polymers 2020, 12, 599. [CrossRef]

51. Ferreira, S.R.; Pepe, M.; Martinelli, E.; de Andrade Silva, F.; Toledo Filho, R.D. Influence of natural fibers characteristics on the interface mechanics with cement based matrices. Compos. Part B Eng. 2018, 140, 183-196. [CrossRef]

52. Ahmad, M.R.; Chen, B.; Oderji, S.Y.; Mohsan, M. Development of a new bio-composite for building insulation and structural purpose using corn stalk and magnesium phosphate cement. Energy Build. 2018, 173, 719-733. [CrossRef]

53. Zadorecki, P.; Flodin, P. Surface modification of cellulose fibers. I. Spectroscopic characterization of surface-modified cellulose fibers and their copolymerization with styrene. J. Appl. Polym. Sci. 1985, 30, 2419-2429. [CrossRef]

54. Zadorecki, P.; Flodin, P. Surface modification of cellulose fibers. II. The effect of cellulose fiber treatment on the performance of cellulose-polyester composites. J. Appl. Polym. Sci. 1985, 30, 3971-3983. [CrossRef]

55. Bilba, K.; Arsene, M.A. Silane treatment of bagasse fiber for reinforcement of cementitious composites. Compos. Part A 2008, 39, 1488-1495. [CrossRef]

56. Chakraborty, S.; Kundu, S.P.; Roy, A.; Adhikari, B.; Majumder, S.B. Polymer modified jute fibre as reinforcing agent controlling the physical and mechanical characteristics of cement mortar. Constr. Build. Mater. 2013, 49, 214-222. [CrossRef]

57. Yan, L.; Kasal, B.; Huang, L. A review of recent research on the use of cellulosic fibres, their fibre fabric reinforced cementitious, geo-polymer and polymer composites in civil engineering. Compos. Part B Eng. 2016, 92, 94-132. [CrossRef] 
58. Vo, L.T.; Navard, P. Treatments of plant biomass for cementitious building materials. Constr. Build. Mater. 2016, 12, 161-176. [CrossRef]

59. Peschard, A.; Govin, A.; Grosseau, P.; Guilhot, B.; Guyonnet, R. Effect of polysaccharides on the hydration of cement paste at early ages. Cem. Concr. Res. 2004, 34, 2153-2158. [CrossRef]

60. Peschard, A.; Govina, A.; Pourchez, J.; Fredon, E.; Bertrand, L.; Maximilien, S.; Guilhot, B. Effect of polysaccharides on the hydration of cement suspension. J. Eur. Ceram. Soc. 2006, 26, 1439-1445. [CrossRef]

61. Dewacker, D.R.; Mcad, B. Cement Mortar Systems Using Blends of Polysaccharides and Cold-Water-Soluble Unmodified Starches. U.S. Patent 5575840, 19 November 1996.

62. Zhang, D.F.; Ju, B.Z.; Zhang, S.F.; He, L.; Yang, J.Z. The study on the dispersing mechanism of starch sulfonate as a water-reducing agent for cement. Carbohydr. Polym. 2007, 70, 363-368. [CrossRef]

63. Ferrández-García, M.T.; García-Ortuño, T.; Ferrández-Villena, M.; Andreu-Rodríguez, J.; Ferrández-García, C.E. Study of the properties of cement boards improved with starch. In Proceedings of the 8th Iberian Congress of Agroengineering, Libro de Actas: Retos de la Nueva Agricultura Mediterránea, Orihuela, Spain, 1-3 June 2015; Universidad Miguel Hernández de Elche: Elche, Spain, 2015; pp. 387-392, ISBN 978-84-16024-30-8.

64. Islam, M.R.; Rahman, F.; Islam, M.N.; Rana, M.N.; Nath, S.K.; Ashaduzzaman, M.; Shams, M.I. Cement-bonded lignocellulosic panel (CLP): A promising environmental friendly construction material for conservation of forest resources. In Handbook of Ecomaterials; Springer: New York, NY, USA, 2018; pp. 1-13. [CrossRef]

65. Onuaguluchi, O.; Banthia, N. Plant-based natural fibre reinforced cement composites: A review. Cem. Concr. Compos. 2016, 68, 96-108. [CrossRef]

66. Deltoro Torró, V.; Jiménez Ruiz, J.; Vilán Fragueiro, X.M. Bases para el Manejo y Control de Arundo donax L. (Caña común). Colección Manuales Técnicos de Biodiversidad; Conselleria d'Infraestructures, Territori i Medi Ambient. Generalitat Valenciana: Valencia, Spain, 2012; ISBN 978-84-482-5777-4.

67. Ferrández García, M.T. Análisis y Desarrollo de Tableros Multicapa de Caña Común (Arundo donax L.). Ph.D. Thesis, Universidad Miguel Hernández, Elche, Spain, 28 July 2008.

68. EN 312. In Particleboards—Specifications; European Committee for Standardization: Brussels, Belgium, 2010.

69. García-Ortuño, T.; Rodríguez, J.; Ferrández-García, M.T.; Ferrández-Villena, M.; Ferrández-García, C.E. Evaluation of the physical and mechanical properties of particleboard made from giant reed (Arundo donax L.). BioResources 2011, 6, 477-486. [CrossRef]

70. Ferrández-García, C.E.; Andreu-Rodríguez, J.; Ferrández-García, M.T.; Ferrández-Villena, M.; García-Ortuño, T. Panels made from giant reed bonded with non-modified starches. BioResources 2012, 7, 5904-5916. [CrossRef]

71. Shon, C.S.; Mukashev, T.; Lee, D.; Zhang, D.; Kim, J.R. Can common reed fiber become an effective construction material? Physical, mechanical, and thermal properties of mortar mixture containing common reed fiber. Sustainability 2019, 11, 903. [CrossRef]

72. EN 326: Wood-based panels, Cutting and Inspection. In Part 1: Sampling and Cutting of Test Pieces and Expression of Test; European Committee for Standardization: Brussels, Belgium, 1994.

73. EN 309: Particleboards. In Definitions and Classification; European Committee for Standardization: Brussels, Belgium, 2005.

74. EN 323: Wood-based panels. In Determination of Density; European Committee for Standardization: Brussels, Belgium, 1993.

75. EN 317: Particleboards and fiberboards. In Determination of Swelling in Thickness after Immersion in Water; European Committee for Standardization: Brussels, Belgium, 1993.

76. EN 319: Particleboards and fiberboards. In Determination of Tensile Strength Perpendicular to the Plane of de Board; European Committee for Standardization: Brussels, Belgium, 1993.

77. EN 310: Wood-based panels. In Determination of Modulus of Elasticity in Bending and of Bending Strength; European Committee for Standardization: Brussels, Belgium, 1993.

78. Giraldo, M.A.; Tobón, J.I. Mineralogical evolution of Portland cement during hydratation process. Dyna 2006, $73,69-81$.

79. Fan, M.; Ndikontar, M.K.; Zhou, X.; Ngamveng, J.N. Cement-bonded composites made from tropical woods: Compatibility of wood and cement. Constr. Build. Mater. 2012, 36, 135-140. [CrossRef] 